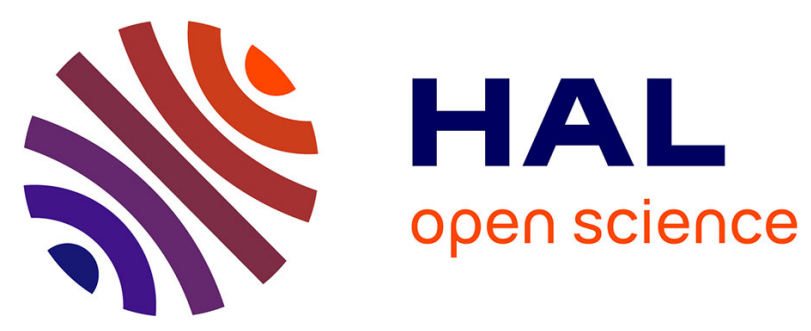

\title{
Time series of the partial pressure of carbon dioxide (2001-2004) and preliminary inorganic carbon budget in the Scheldt plume (Belgian coastal waters)
}

Laure-Sophie Schiettecatte, Frédéric Gazeau, Claar van Der Zee, Natacha Brion, Alberto Borges

\section{To cite this version:}

Laure-Sophie Schiettecatte, Frédéric Gazeau, Claar van Der Zee, Natacha Brion, Alberto Borges. Time series of the partial pressure of carbon dioxide (2001-2004) and preliminary inorganic carbon budget in the Scheldt plume (Belgian coastal waters). Geochemistry, Geophysics, Geosystems, 2006, 7 (6), pp.n/a-n/a. 10.1029/2005GC001161 . hal-03334223

\section{HAL Id: hal-03334223 \\ https://hal.science/hal-03334223}

Submitted on 4 Sep 2021

HAL is a multi-disciplinary open access archive for the deposit and dissemination of scientific research documents, whether they are published or not. The documents may come from teaching and research institutions in France or abroad, or from public or private research centers.
L'archive ouverte pluridisciplinaire HAL, est destinée au dépôt et à la diffusion de documents scientifiques de niveau recherche, publiés ou non, émanant des établissements d'enseignement et de recherche français ou étrangers, des laboratoires publics ou privés. 


\title{
Time series of the partial pressure of carbon dioxide (2001- 2004) and preliminary inorganic carbon budget in the Scheldt plume (Belgian coastal waters)
}

Laure-Sophie Schiettecatte

Chemical Oceanography Unit, Interfacultary Centre for Marine Research, Université de Liège, Allée du 6 Août 17, 4000 Liège, Belgium (laure-sophie.schiettecatte@ulg.ac.be)

\section{Frédéric Gazeau}

Centre for Estuarine and Marine Ecology, Netherlands Institute of Ecology (NIOO-KNAW), Korringaweg 7 P.O. Box 140, 4400AC Yerseke, Netherlands

\section{Claar van der Zee}

Océanographie Chimique et Géochimie des Eaux, Campus de la Plaine, Université Libre de Bruxelles, CP 208, Boulevard du Triomphe, 1050 Brussels, Belgium

\section{Natacha Brion}

Analytische en Milieu Chemie, Vrije Universiteit Brussel, Pleinlaan 2, 1050 Brussels, Belgium

\author{
Alberto V. Borges \\ Chemical Oceanography Unit, Interfacultary Centre for Marine Research, Université de Liège, Allée du 6 Août 17, 4000 \\ Liège, Belgium
}

[1] A 4-year time series (2001-2004) of the partial pressure of $\mathrm{CO}_{2}\left(\mathrm{pCO}_{2}\right)$ and air-sea $\mathrm{CO}_{2}$ fluxes is reported in the Scheldt estuarine plume. This system is oversaturated in $\mathrm{CO}_{2}$ with respect to the atmosphere, except during the spring phytoplanktonic bloom, and acts as a net source of $\mathrm{CO}_{2}$ to the atmosphere of $0.7 \mathrm{~mol} \mathrm{C} \mathrm{m}^{-2} \mathrm{yr}^{-1}$ that represents 7 to $27 \%$ of the inner Scheldt estuary $\mathrm{CO}_{2}$ emission. Results also highlight that a high spatial and temporal coverage of the surface $\mathrm{pCO}_{2}$ in coastal ecosystems is crucial for reliable estimations of air-sea $\mathrm{CO}_{2}$ fluxes. The seasonal variations of $\mathrm{pCO}_{2}$ seem to be more dominated by biological activities (photosynthesis/respiration) than by temperature change. A stochiometrically linked $\mathrm{C} / \mathrm{P}$ mass balance budget failed to provide net ecosystem production estimates consistent with the $\mathrm{pCO}_{2}$ dynamics in this area. It is hypothesized that this discrepancy is related to physiological characteristics of the dominant phytoplanktonic species (Phaeocystis sp.) within the studied area. On the basis of a preliminary dissolved inorganic carbon input/output budget, the annual emission of $\mathrm{CO}_{2}$ toward the atmosphere seems to be largely due to the outgassing of the inputs of $\mathrm{CO}_{2}$ from the inner Scheldt estuary, rather than due to organic carbon degradation.

Components: 9857 words, 8 figures, 3 tables.

Keywords: $\mathrm{CO}_{2}$ air-sea fluxes; Belgian coastal water; Scheldt estuary.

Index Terms: 4806 Oceanography: Biological and Chemical: Carbon cycling (0428).

Received 10 October 2005; Revised 18 March 2006; Accepted 3 April 2006; Published 14 June 2006.

Schiettecatte, L.-S., F. Gazeau, C. van der Zee, N. Brion, and A. V. Borges (2006), Time series of the partial pressure of carbon dioxide (2001-2004) and preliminary inorganic carbon budget in the Scheldt plume (Belgian coastal waters), Geochem. Geophys. Geosyst., 7, Q06009, doi:10.1029/2005GC001161. 


\section{Introduction}

[2] Coastal environments are important biogeochemical pathways between land and the open ocean that significantly modify the flows of matter and energy between the latter two systems. They receive and exchange considerable amounts of dissolved and particulate organic matter and nutrients, freshwater, energy and contaminants [Smith and Hollibaugh, 1993; Gattuso et al., 1998; Wollast, 1998]. Recent studies highlighted the significance of continental shelves in the global carbon cycle and in particular for the budgets of $\mathrm{CO}_{2}$ [Tsunogai et al., 1999; Frankignoulle and Borges, 2001; Cai et al., 2003; Thomas et al., 2004, 2005a]. On the basis of an exhaustive literature survey, Borges et al. [2005] showed that marginal seas on the whole act as sinks of atmospheric $\mathrm{CO}_{2}$ of about $-0.45 \mathrm{PgC} \mathrm{yr}^{-1}$ that leads to a major revaluation of the oceanic sink for atmospheric $\mathrm{CO}_{2}$, since open oceanic waters are a $\mathrm{CO}_{2}$ sink of about $-1.6 \mathrm{PgC} \mathrm{yr}^{-1}$ [Takahashi et al., 2002]. Nearshore coastal systems (estuaries, saltmarsh waters, mangrove waters, coral reefs, and coastal upwelling systems) act as sources of $\mathrm{CO}_{2}$ and a preliminary upscaling suggests that the overall emission of $\mathrm{CO}_{2}$ from these systems could

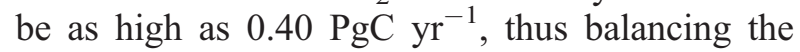
$\mathrm{CO}_{2}$ sink associated to marginal seas [Borges, 2005; Borges et al., 2005]. Estuaries are the largest contributors to this emission of $\mathrm{CO}_{2}$, accounting for about $0.34{\mathrm{PgC} \mathrm{yr}^{-1}}^{-}$. However, due to an insufficient geographical coverage of the available data, the estimation of $\mathrm{CO}_{2}$ air-water fluxes from coastal environments on a global scale remains highly uncertain, but potentially relevant.

[3] Estuaries can be divided into an inner part (extending from the geographical mouth to the uppermost limit of the tidal river) and an outer estuary defined by Ketchum [1983] as "a plume of freshened water which floats on the more dense coastal water and can be traced for many miles from the geographical mouth of the estuary". According to Schettini et al. [1998], two types of outer estuaries can be distinguished depending on the degree of salinity mixing and intensity of the freshwater discharge: "In riverine plumes, freshwater discharge dominates over tidal and other effects, resulting in freshwater being directly injected over shelf waters (e.g., the Mississippi or the Rhine river plumes). In estuarine plume, much of the mixing takes place within an enclosed basin before being released to shelf waters". In outer estuaries, intense biogeochemical transformations (affecting both particulate and dissolved organic and inorganic materials) occur on short time (scale of days to week) and space scales [e.g., Dagg et al., 2004].

[4] The inner Scheldt estuary, located between Netherlands and Belgium (Figure 1), is a wellmixed macrotidal estuary, with a low freshwater discharge $\left(4 \mathrm{~km}^{3} \mathrm{yr}^{-1}\right)$. The brackish part extends up to $100 \mathrm{~km}$ inland and drains a heavily populated and industrial basin [Wollast, 1988]. Lack of sewage treatment has led to a high content of organic matter and nutrients in these waters and a strong heterotrophic status with an estimated annual net ecosystem production (NEP) of -15 to $-40 \mathrm{~mol} \mathrm{C}$ $\mathrm{m}^{-2} \mathrm{yr}^{-1}$ in the inner estuary [Gazeau et al., 2005]. The estuarine plume is located along the Belgian coast deflected by the southwestward residual currents [Nihoul and Ronday, 1975; Yang, 1998]. The water column is well-mixed through the year due to its shallowness (mean depth of $20 \mathrm{~m}$ ) and strong tidal currents. A high turbidity zone extends from the mouth of the Scheldt estuary and along the Belgian coast [Nihoul and Hecq, 1984; Wollast, 1988]. The suspended particulate matter mainly originates from the Dover Strait according to de Haas et al. [2002] and Fettweis and Van den Eynde [2003]. High nutrient inputs from the Scheldt have led to a distrophization of the Belgian coast and recurrent spring blooms of Phaeocystis $s p$. The phytoplanktonic seasonal succession consists in consecutive blooms of diatoms and Phaeocystis occurring between February and May. A last diatom bloom occurs also in summer [Reid et al., 1990; Rousseau et al., 2002]. The spring bloom represents up to $77 \%$ of the annual net primary production with Phaeocystis sp. as the main contributor (55\% [Lancelot et al., 2005]).

[5] The main objective of the present paper is to investigate partial pressure of $\mathrm{CO}_{2}\left(\mathrm{pCO}_{2}\right)$ dynamics in the surface waters of the Scheldt plume using a 4-year time series. Two data analysis approaches are presented. The first one is based on a high temporal data set of $\mathrm{pCO}_{2}$ (frequency sampling twice a week) at a fixed station (Zeebrugge station) that allows to highlight the relative importance of temperature change and biological activities involved in the seasonal DIC dynamics. The second approach is a high spatial coverage of $\mathrm{pCO}_{2}$ (the survey area approach, one to three surveys per month) that allows us to compute the air-sea $\mathrm{CO}_{2}$ fluxes taking into account the strong spatial heterogeneity of the system. Moreover, the impact of biological activities on the carbon cycle in the 


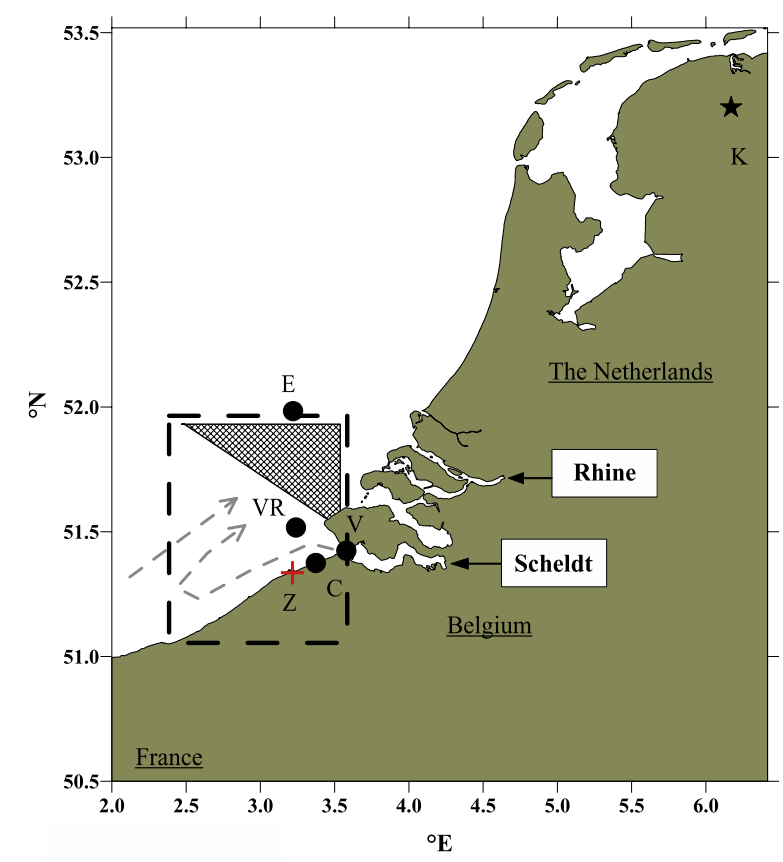

Figure 1. Map of the study site showing Zeebrugge station (Z, red cross), location of meteorological stations (E, Europlatform; V.R., Vlakte van de Raan; C, Cadzand; and V, Vlissingen; black circles) where wind speed data was acquired and atmospheric $\mathrm{pCO}_{2}$ station (K, Kollumerwaard; black star). Hatched arrows represent the residual circulation off the Belgian coast. Hatched area represents the region not taken into account in the air-sea $\mathrm{CO}_{2}$ flux computations.

Scheldt plume is assessed from NEP estimates based on a stochiometrically linked $\mathrm{C} / \mathrm{P}$ mass balance budget (Land-Ocean Interaction in the Coastal Zone; LOICZ). Finally, on the basis of these results and estimates of dissolved inorganic carbon (DIC) inputs from the Scheldt estuary, a tentative DIC budget is established to unravel the main processes controlling on an annual scale the air-sea $\mathrm{CO}_{2}$ fluxes in the Scheldt estuarine plume.

\section{Material and Methods}

[6] Data were obtained from January 2001 to December 2004 on board the R/V Belgica. Figure 2 shows the sampling frequency for the fixed Zeebrugge station approach (red squares) and for the survey area approach (blue circles).

\subsection{Partial Pressure of $\mathrm{CO}_{2}$ and Air-Sea $\mathrm{CO}_{2}$ Fluxes}

[7] A nondispersive infrared gas analyzer (IRGA, Li-Cor ${ }^{\circledR}$, Li-6262) and an equilibrator were used to measure the $\mathrm{pCO}_{2}$ (for details on design and performance tests, refer to Frankignoulle et al. [2001]). The IRGA was calibrated weekly using pure nitrogen (Air Liquide Belgium) and two gas mixtures with a $\mathrm{CO}_{2}$ molar fraction of 366 and 810 ppm (Air Liquide Belgium) that were calibrated against National Oceanic and Atmospheric Administration standards of a $\mathrm{CO}_{2}$ molar fraction of 361 and $774 \mathrm{ppm}$. The temperature at the outlet of the equilibrator was monitored with a platinum resistance thermometer $\left(\mathrm{PT} 100\right.$, METROHM $\left.^{\mathbb{R}}\right)$. The $\mathrm{pCO}_{2}$ values were corrected for the temperature difference between in situ seawater and water in the equilibrator using the algorithm proposed by Copin-Montégut [1988]. Salinity, temperature and $\mathrm{pCO}_{2}$ were sampled with a 1 minute frequency from the surface seawater supply of the ship (pump inlet at a depth of $2.5 \mathrm{~m}$ ). Salinity and temperature were measured using a SeaBird ${ }^{\mathbb{R}}$ SBE21 thermosalinograph.

[8] $\mathrm{pCO}_{2}$, salinity and temperature were interpolated using the Krigging method with Golden Software Surfer 8. Interpolated data were extracted for salinities up to 34 corresponding to the limit of the outer Scheldt plume used by Borges and Frankignoulle [2002]. The flux of $\mathrm{CO}_{2}$ across the air-sea interface $(\mathrm{F})$ was computed from the $\mathrm{pCO}_{2}$ air-sea gradient $\left(\Delta \mathrm{pCO}_{2}=\mathrm{pCO}_{2} \mathrm{sea}-\mathrm{pCO}_{2}\right.$ air $)$, the solubility coefficient of $\mathrm{CO}_{2}(\alpha)$, and the gas transfer velocity $(k)$ according to

$$
\mathrm{F}=\alpha k \Delta \mathrm{pCO}_{2}
$$

A positive flux corresponds to a transfer of $\mathrm{CO}_{2}$ from the water to the atmosphere.

[9] We used the $k$-wind parameterization given by Nightingale et al. [2000] (referred to hereafter as N\&al), established in the Southern Bight of the North Sea (SBNS), close to our study area. Alternate $k$-wind parameterizations were also used to estimate the sensitivity of the computed fluxes to this parameter [Liss and Merlivat, 1986; Wanninkhof, 1992; Wanninkhof and McGillis, 1999; referred to as L\&M, W, and W\&McG, respectively] and to compare with previous studies carried out in this area. $k$ values were computed using hourly wind speed values from 4 meteorological stations provided by the Royal Netherlands Meteorological Institute (http://www.knmi.nl/ samenw/hydra): Cadzand $\left(3.37^{\circ} \mathrm{E} 51.38^{\circ} \mathrm{N}\right)$, Vlissingen $\left(3.58^{\circ} \mathrm{E} 51.42^{\circ} \mathrm{N}\right)$, Vlakte van de Raan $\left(3.24^{\circ} \mathrm{E} 51.52^{\circ} \mathrm{N}\right)$ and Europlatform $\left(3.22^{\circ} \mathrm{E}\right.$ $51.98^{\circ} \mathrm{N}$ ), shown in Figure 1. Vlakte van de Raan was chosen as the reference meteorological station, 
2001

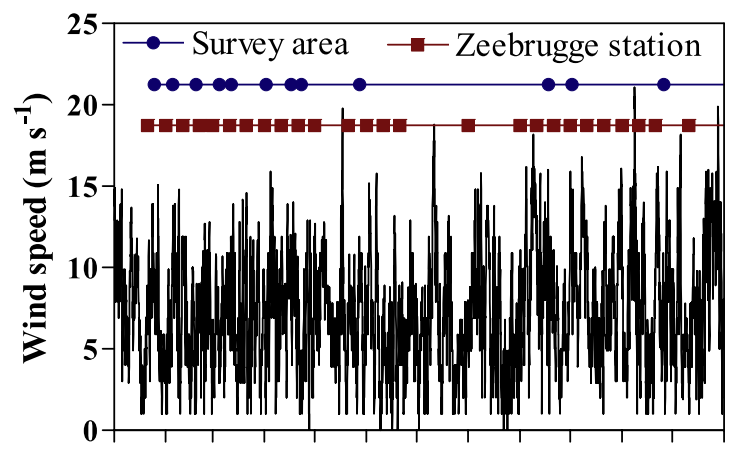

2003

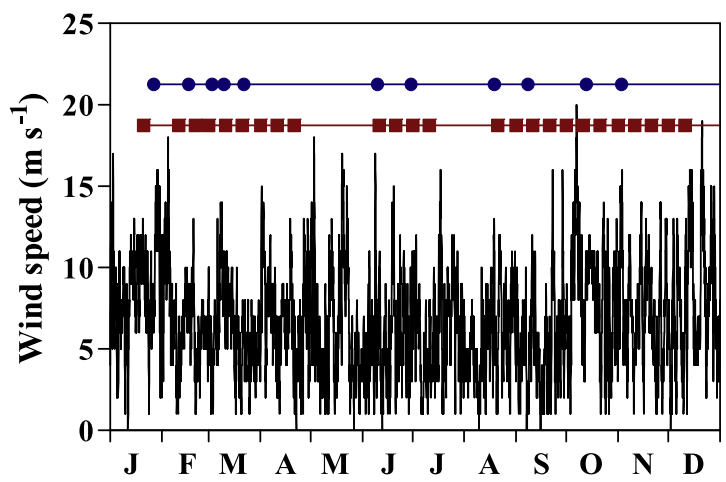

2002

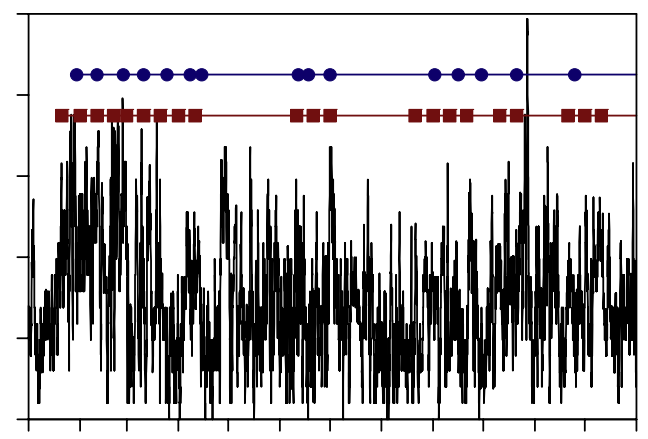

2004

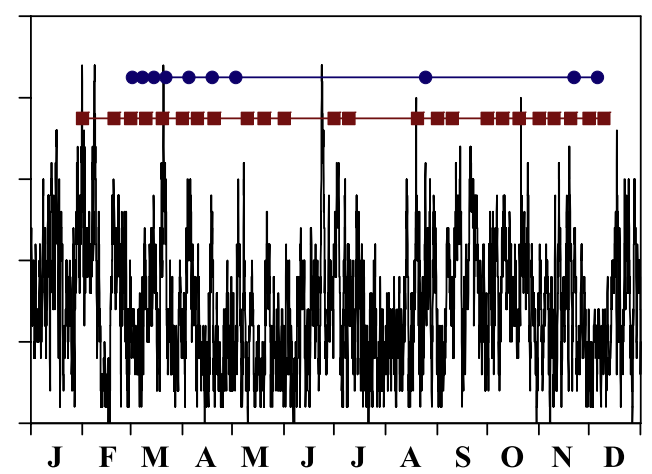

Figure 2. Wind speed data measured at station Vlakte van de Raan from 2001 to 2004 and temporal coverage for the survey area and Zeebrugge station approaches (blue circles and red squares, respectively).

being located in the plume. However, air-sea $\mathrm{CO}_{2}$ fluxes were also computed using wind speed data from the 3 other stations (one offshore and two coastal referenced stations) in order to assess the sensitivity of the computed fluxes to this variable. Monthly values of atmospheric $\mathrm{pCO}_{2}$ data used were measured at station Kollumerwaard in Netherlands $\left(6.17^{\circ} \mathrm{E} 53.20^{\circ} \mathrm{N}\right)$ from the Dutch National Air Quality Monitoring Network supplied by the National Institute of Public Health and Environment. Atmospheric $\mathrm{pCO}_{2}$ data were converted into $\mathrm{pCO}_{2}$ in wet air $\left(\mathrm{pCO}_{2}\right.$ air) according to Dickson and Goyet [1994].

\subsection{Modeling Budget}

[10] A dissolved inorganic phosphorus (DIP) budget in the Scheldt plume for year 2003 was carried on using the $\mathrm{C} / \mathrm{N} / \mathrm{P}$ stochiometrically Land-Ocean Interaction in the Coastal Zone (LOICZ) method given by Gordon et al. [1996]. As the water column is well-mixed through the year, the Scheldt plume was considered as a one-layer box. Residual inputs and mixing fluxes from the inner Scheldt estuary as well as mixing fluxes with the open oceanic water (SBNS) were considered as shown in Figure 3. Lacroix et al. [2004] reported that Belgian coastal waters could be influenced by inputs from the Rhine estuary. However, as the proportion of water masses coming from the Rhine is relatively small in this area based on total alkalinity (TA) distributions (L.-S. Schiettecatte, unpublished data) water and nutrient inputs from this estuary were neglected. Moreover, precipitation and evaporation were not taken into account, as these two quantities compensate each other [OSPARCOM, 2002]. Therefore the residual transport $\left(\mathrm{Vr}_{1}\right)$ between the plume box and the SBNS was considered to be equivalent to the Scheldt discharge $\left(\mathrm{Vr}_{2}\right.$; Figure 3). Freshwater discharge data in the inner Scheldt estuary were provided by the Ministerie van de Vlaamse Gemeenschap Afdeling Waterbouwkundig Laboratorium en Hydrologisch Onderzoek. According to Soetaert et al. [2006], these data must be corrected for lateral inputs to estimate the discharge at the mouth. These lateral inputs represent on average $32 \%$ of the freshwater flow entering the estuary: $10 \%$ from the Antwerpen harbor, 12\% from the Gent-Terneuzen channel and $10 \%$ from diffusive sources. The mixing transport between the plume 

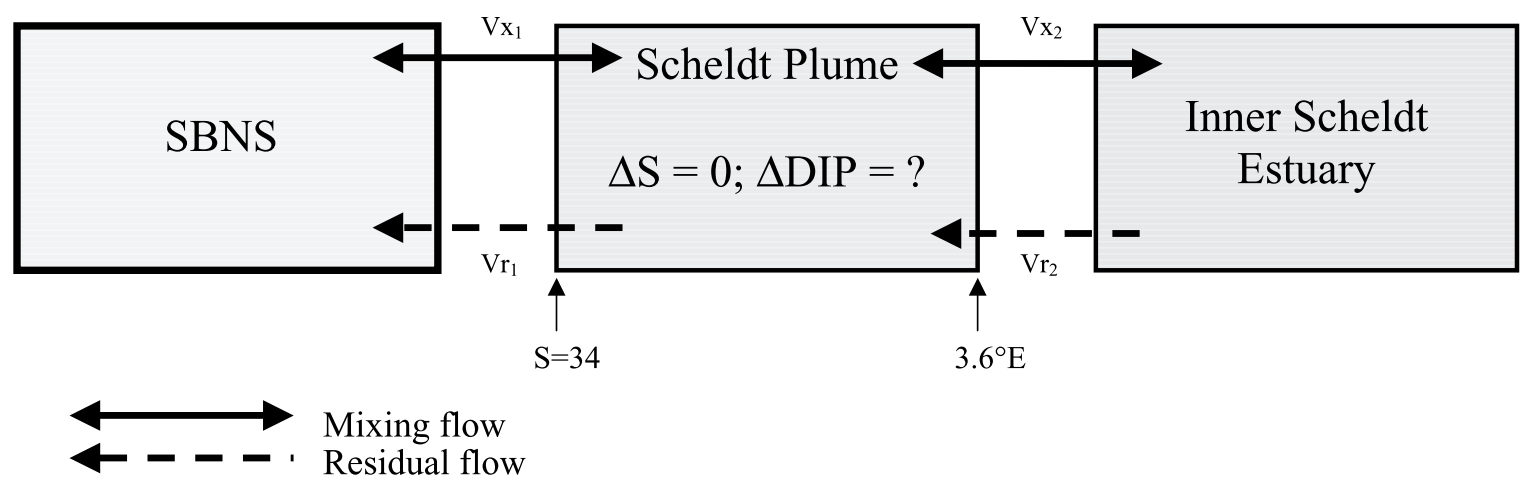

Figure 3. Land Ocean Interaction in the Coastal Zone (LOICZ) budgeting approach applied to dissolved inorganic phosphorus (DIP) in the Scheldt plume. Mixing exchange terms $\left(\mathrm{Vx}_{1}\right.$ and $\left.\mathrm{Vx}_{2}\right)$ were considered between the plume and the Southern Bight of the North Sea (SBNS) and between the plume and the inner Scheldt estuary. Residual fluxes $\left(\mathrm{Vr}_{1}\right.$ and $\left.\mathrm{Vr}_{2}\right)$ correspond to the water discharge from the inner Scheldt estuary (see text for details). Salinity 34 represents the outer limit of the Scheldt plume, and $3.6^{\circ} \mathrm{E}$ was considered as the limit between the inner Scheldt estuary and the plume.

and SBNS $\left(\mathrm{Vx}_{1}\right)$ was estimated on the basis of salinity data which is a conservative parameter which is assumed to be at steady state in the plume over a tidal cycle $(\mathrm{dS} / \mathrm{dt}=0)$, following the equation

$$
\begin{aligned}
\mathrm{Vx}_{1}= & {\left[\mathrm{Vr}\left(\mathrm{Sr}_{2}-\mathrm{Sr}_{1}\right)-\mathrm{Vx}_{2}\left(\mathrm{~S}_{\text {plume }}-\mathrm{S}_{\mathrm{Scheldt}}\right)\right] / } \\
& \left(\mathrm{S}_{\text {plume }}-\mathrm{S}_{\mathrm{SBNS}}\right)
\end{aligned}
$$

where $\mathrm{S}_{\text {plume, }}, \mathrm{S}_{\mathrm{Scheldt}}$ and $\mathrm{S}_{\mathrm{SBNS}}$ are average salinities in the plume, Scheldt mouth and SBNS boxes, respectively. Monthly estimates of mixing fluxes between the plume and the inner Scheldt estuary $\left(\mathrm{Vx}_{2}\right)$ were given by Gazeau et al. [2005] using the same procedure for year 2003. For more details on the calculation procedure, refer to Gordon et al. [1996].

[11] DIP data in 2003 for the Scheldt plume and SBNS boxes were acquired in the present study and completed with data from van der Zee and Chou [2005], from the Belgian Marine Data Center (BMDC, http://www.mumm.ac.be/datacentre/) and EUROTROPH (Nutrients Cycling and the Trophic Status of Coastal Ecosystems; http://www.ulg.ac.be/oceanbio/eurotroph/) and CANOPY (Carbon, Nitrogen and Phosphorus Cycling in the North Sea) projects. DIP data for the inner Scheldt estuary box were given by Gazeau et al. [2005]. Phosphorus atmospheric deposition represents less than $2 \%$ of the riverine inputs in the area [OSPAR$C O M, 2002]$, so this term was neglected. Samples for DIP of the present study were collected with a frequency of $30 \mathrm{~min}$ from the seawater supply (depth of $2.5 \mathrm{~m}$ ), filtered on cellulose acetate filters and kept frozen $\left(-20^{\circ} \mathrm{C}\right)$ until analysis using the spectrophotometric method given by Grasshoff et al. [1983].

[12] As DIP is not a conservative parameter and could be influenced by processes other that transport and dilution, nonconservative fluxes (basically, deviation from the dilution/mixing line) of DIP $(\Delta \mathrm{DIP})$ in the plume were estimated as the difference between DIP outputs and inputs in the plume box [Gordon et al., 1996]. NEP (p-r in the LOICZ terminology) is the difference between gross primary production (GPP) and community respiration (CR) [Odum, 1956] and was calculated from the nonconservative fluxes of DIP, assuming that these fluxes are only related to biological activity, following the equation

$$
\mathrm{NEP}=-\Delta \mathrm{DIP} \cdot(\mathrm{C}: \mathrm{P})_{\text {part }}
$$

where NEP is expressed in mmol $\mathrm{C} \mathrm{m}^{-2} \mathrm{~d}^{-1}$, $\Delta \mathrm{DIP}$ is the nonconservative flux of DIP (mmol P $\left.\mathrm{m}^{-2} \mathrm{~d}^{-1}\right)$ and $(\mathrm{C}: \mathrm{P})_{\text {part }}$ is the particulate $\mathrm{C}: \mathrm{P}$ ratio (a value of 106:1 was used according to the Redfield stoichiometry).

[13] Error propagations were performed on mean value of each parameter used for the DIP budget using a Monte Carlo procedure on Matlab 7. Mean values of salinity, freshwater discharge and DIP were randomly changed over one thousand iterations within $95 \%$ confidence interval.

\subsection{Estimation of the DIC Inputs From the Inner Scheldt Estuary}

[14] Inputs of DIC from the inner Scheldt estuary to the plume were calculated using the apparent 


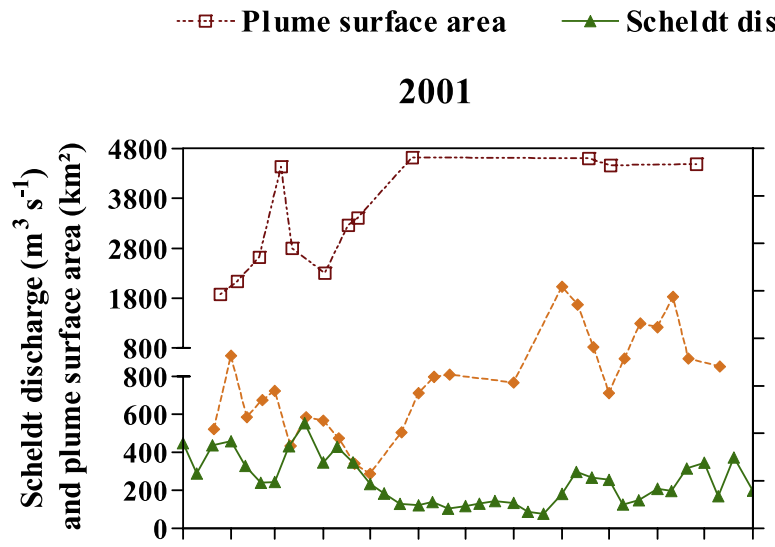

salinity at Zeebrugge station

\section{3}

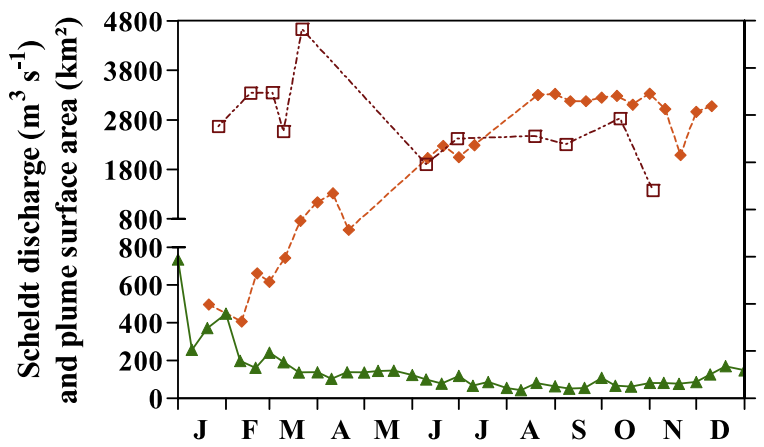

2002

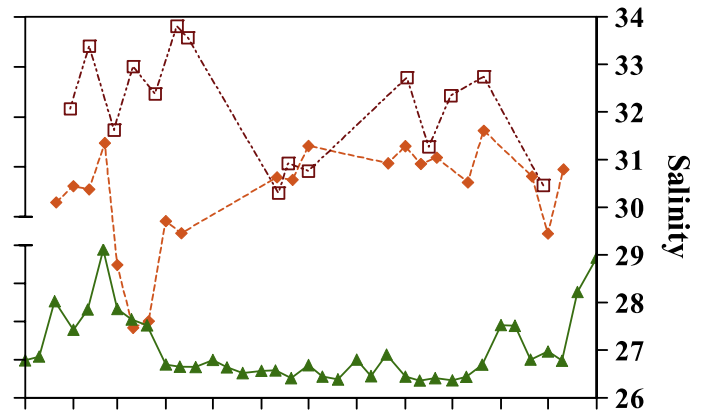

2004

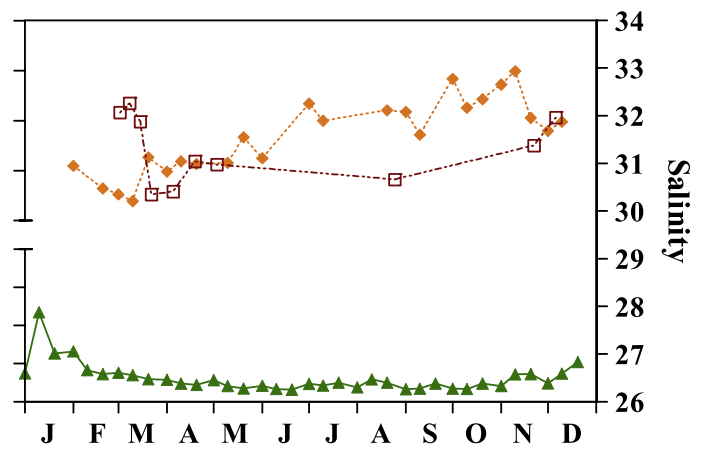

Figure 4. Water discharge from the inner Scheldt estuary in $\mathrm{m}^{3} \mathrm{~s}^{-1}$ (green triangles), surface area of the Scheldt plume in $\mathrm{km}^{2}$ (red squares), and average salinity at the Zeebrugge station (orange diamonds) from 2001 to 2004.

zero end-member method (AZE) according to Kaul and Froelich [1984], from monthly DIC profiles from salinity 9 to 30 [Gazeau et al., 2005], as DIC profiles show nonconservative behavior between salinities 0 to 9 due to strong heterotrophic processes. These fluxes correspond to fluxes of the DIC that can be exchanged with the atmosphere (excess DIC or $\triangle \mathrm{DIC}$ ) that is computed from the difference between the observed DIC and DIC calculated if the sample was at equilibrium with the atmosphere. $\triangle \mathrm{DIC}$ profiles were linear in the inner Scheldt $\left(\mathrm{r}^{2}\right.$ ranging from 0.95 to 0.99 from salinities 9 to 30). Transfer of $\Delta \mathrm{DIC}$ (T $\Delta \mathrm{DIC}$ ) from the inner Scheldt was computed from the monthly Scheldt discharge and $\Delta \mathrm{DIC}_{0}$ corresponding to the $\triangle \mathrm{DIC}$ value computed at salinity 0 from linear regression.

\section{Results and Discussion}

\subsection{Dynamics of $\mathrm{pCO}_{2}$ in Surface Waters}

[15] Figure 4 shows the mean salinity observed at Zeebrugge, the surface area of the Scheldt plume and the water discharge from the inner Scheldt estuary from 2001 to 2004 . The surface area of the plume ranged between 800 and $4800 \mathrm{~km}^{2}$, with highest values observed from June to December 2001 and in spring of 2002 and 2003. Average salinity at Zeebrugge (ranging from 27 to 33 ) and the surface area of the plume showed no clear seasonal trends. Salinity increased and stabilized around 32 from August 2003 through 2004. The strongest freshwater discharges occurred during winter (up to $800 \mathrm{~m}^{3} \mathrm{~s}^{-1}$ ) in response to higher precipitation. During periods of high freshwater discharge, one would intuitively expect an increase of the surface area of the plume and a decrease of salinity. However, this was not always verified as shown in Figure 4. Nihoul and Ronday [1975] and Yang [1998] suggested that the water from the Scheldt mouth is deflected in a southwestward direction resulting from residual currents. Yang [1998] reported that changes of salinity in the Scheldt plume are mainly related to wind stress (intensity and direction). Along shore southeastward and on shore winds induce an increase of salinity, while along shore northeastward and offshore winds have the reverse effect. The surface area of the Scheldt plume results from a complex 
2001

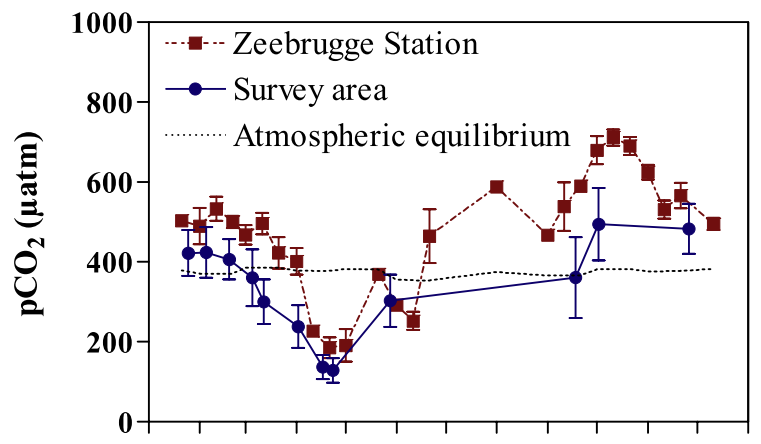

2003

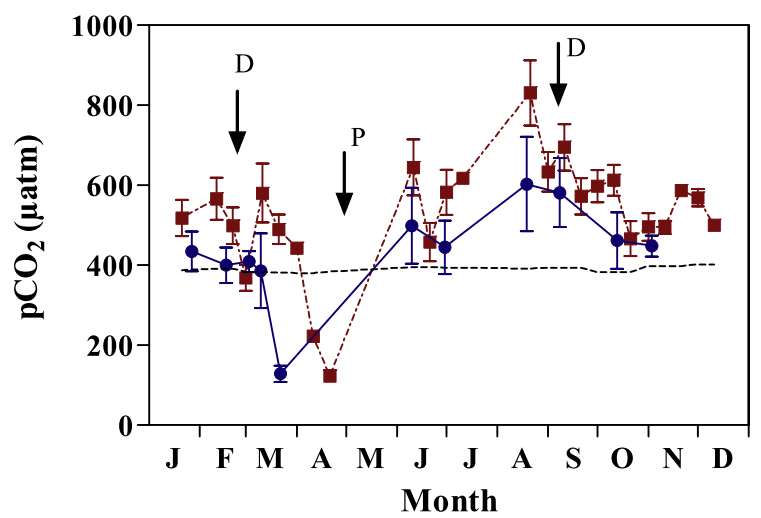

2002

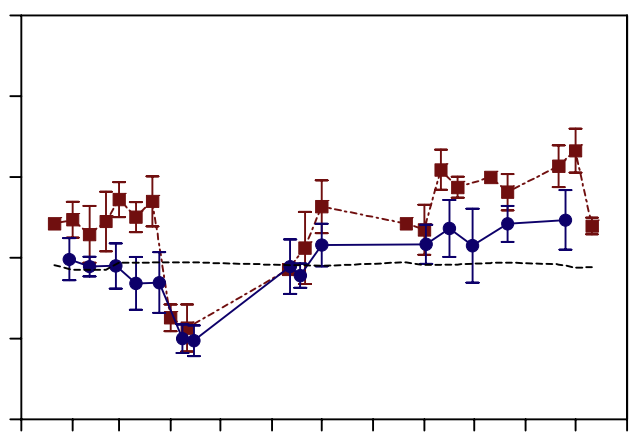

2004

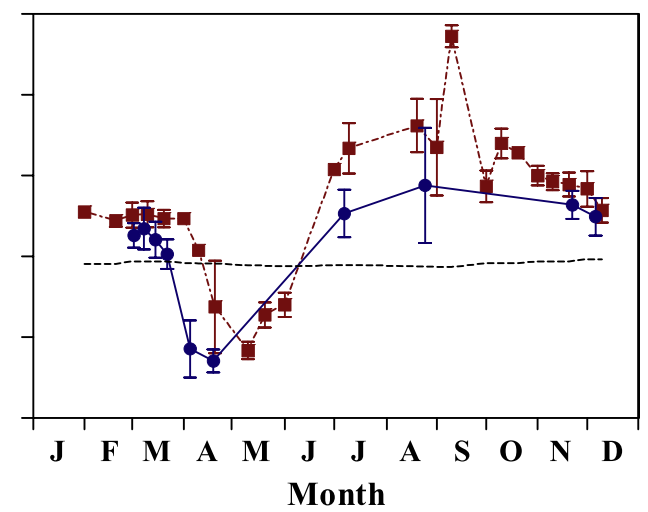

Figure 5. Averaged $\mathrm{pCO}_{2}$ ( $\mu \mathrm{atm}$ ) on surface waters of the Scheldt plume (survey approach; blue circles) and at Zeebrugge station (red squares) from 2001 to 2004. Data are mean \pm standard deviation (SD). The dotted line represents atmospheric $\mathrm{pCO}_{2}$. $\mathrm{P}$ and $\mathrm{D}$ refer to Phaeocystis $s p$. and diatoms, respectively.

combination of residual currents (associated to tides), wind induced currents and freshwater discharge, so that no obvious correlations between salinity, surface area and freshwater discharge are apparent (Figure 4).

[16] Figure 5 shows the seasonal cycle of $\mathrm{pCO}_{2}$ in surface seawaters at Zeebrugge station and from the survey area approach. The surface waters at Zeebrugge station show stronger $\mathrm{CO}_{2}$ oversaturation with respect to the atmosphere than the whole Scheldt plume. The Zeebrugge station was characterized by rather low salinities (Figure 4), while the survey area approach values reflected the overall range of salinities (and mixing) in the Scheldt plume. Most of the time, the Scheldt plume showed a profile against salinity typical for estuarine environments with $\mathrm{pCO}_{2}$ increasing with decreasing salinities (data not shown). Hence $\mathrm{pCO}_{2}$ values at the Zeebrugge station tended to be higher than average values from the survey area approach. The range of $\mathrm{pCO}_{2}$ values was similar from one year to another, with minimal values of around $100 \mu \mathrm{atm}$ and maximal values of 600 and $900 \mu \mathrm{atm}$, for the survey area approach and Zeebrugge station, respectively. In 2003 and 2004, a stronger decrease of $\mathrm{pCO}_{2}$ during the spring phytoplanktonic bloom was observed in comparison to 2001 and 2002.

[17] The seasonal succession of phytoplanktonic blooms as described by Reid et al. [1990] and Rousseau et al. [2002], was apparent in the successive decreases of $\mathrm{pCO}_{2}$ observed in 2003 (Figure 5). The diatom bloom started in February, followed by a bloom of diatoms-Phaeocystis $s p$. from March to May, and ended with a small diatom bloom in late August/early September. The increase of $\mathrm{pCO}_{2}$ values observed during summer was due to heterotrophic processes (see hereafter). The $\mathrm{pCO}_{2}$ decrease in the whole plume occurred earlier than at station Zeebrugge. This was related to the onset of the spring phytoplanktonic bloom in the offshore coastal waters, due to higher light penetration in the water column [Borges and Frankignoulle, 1999, 2002; van der Zee and Chou, 2005].

[18] The method developed by Takahashi et al. [2002] was used to separate the seasonal effect of 

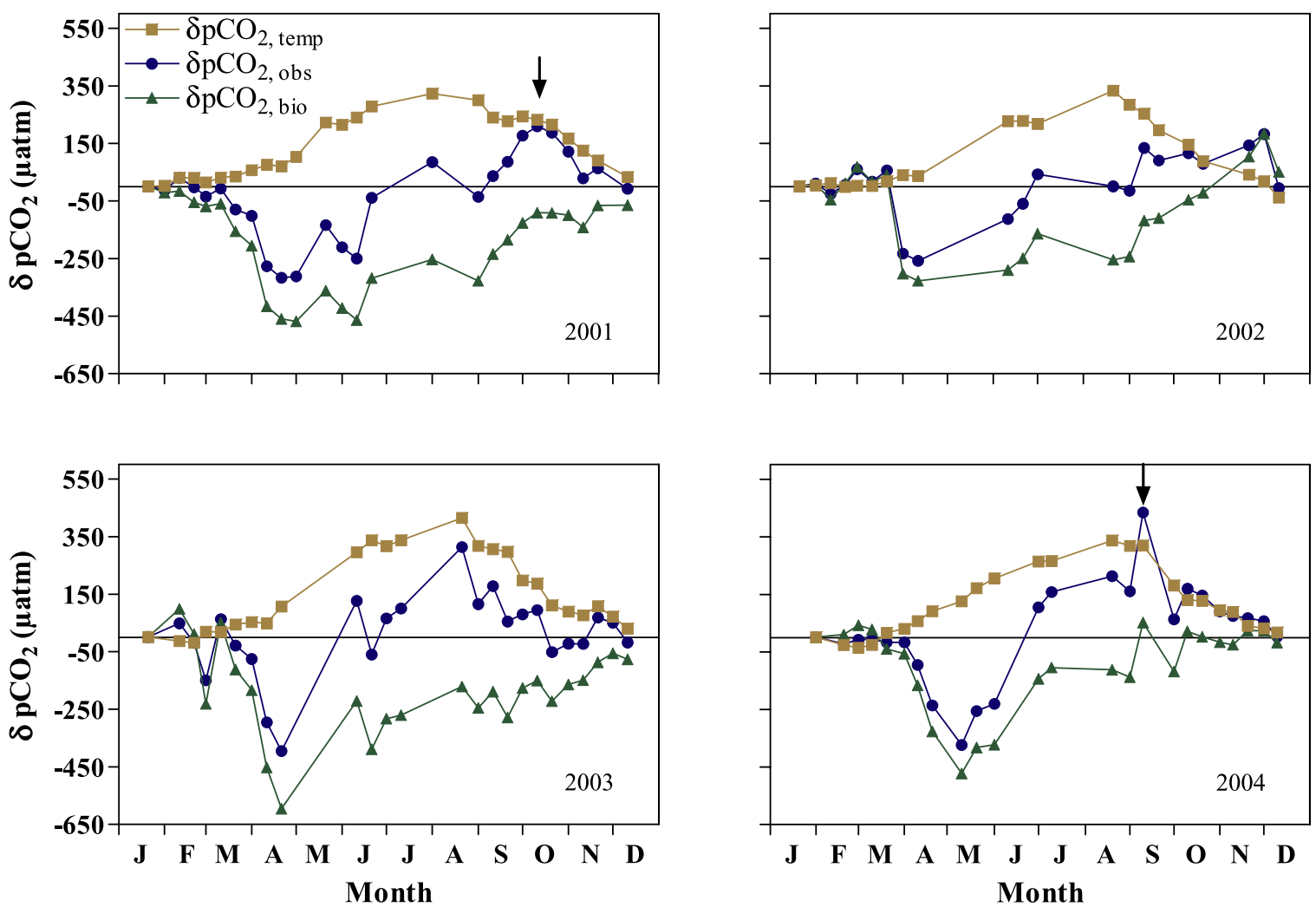

Figure 6. $\delta \mathrm{pCO}_{2}$, obs (blue circles), $\delta \mathrm{pCO}_{2}$, temp (brown squares), and $\delta \mathrm{pCO}_{2}$, bio (green triangles) in $\mu$ atm, from 2001 to 2004. See text for details on the calculations of $\delta \mathrm{pCO}_{2}$. Arrows refer to low salinity events.

biological processes (B) and temperature (T) on $\mathrm{pCO}_{2}$ dynamics over an annual cycle. A ratio of temperature over biology $(\mathrm{T} / \mathrm{B})$ greater than 1 implies the dominance of temperature effects over biological processes on $\mathrm{pCO}_{2}$ dynamics. Biological and temperature effects were respectively calculated according to the following equations:

(B) $\mathrm{pCO}_{2, \text { bio }}=\mathrm{pCO}_{2}\left(\mathrm{~T}_{\text {mean }}\right)=\mathrm{pCO}_{2}$ (obs)

$$
\cdot \exp \left[0.0423 \cdot\left(\mathrm{T}_{\text {mean }}-\mathrm{T}_{\mathrm{obs}}\right)\right]
$$

$$
\begin{aligned}
\mathrm{pCO}_{2, \text { temp }}= & \mathrm{pCO}_{2}\left(\mathrm{~T}_{\text {obs }}\right)=\left(\text { mean annual } \mathrm{pCO}_{2}\right) \\
& \cdot \exp \left[0.0423 \cdot\left(\mathrm{T}_{\text {obs }}-\mathrm{T}_{\text {mean }}\right)\right]
\end{aligned}
$$

where $\mathrm{T}_{\text {mean }}$ is the mean annual temperature (10.7, $11.5,12.8$ and $10.6^{\circ} \mathrm{C}$ for $2001,2002,2003$ and 2004, respectively) and $\mathrm{T}_{\mathrm{obs}}$ is the in situ temperature.

[19] Seasonal effects of biological processes and temperature were determined, respectively, from the amplitude of $\mathrm{pCO}_{2}\left(\mathrm{~T}_{\text {mean }}\right)$ and $\mathrm{pCO}_{2}\left(\mathrm{~T}_{\mathrm{obs}}\right)$ derived from equations (3) and (4). Figure 6 shows the seasonal variations of the $\mathrm{p}_{\mathrm{CO}}$, obs, $\delta \mathrm{pCO}_{2}$, bio, $\delta \mathrm{pCO}_{2}$, temp (calculated as the difference between $\mathrm{pCO}_{2}$ monthly averaged values and a reference, here $\mathrm{pCO}_{2}$ averaged value for January of each year) from 2001 to 2004 at the Zeebrugge station. Maximum $\mid \delta \mathrm{pCO}_{2}$, bio $\mid$ values were observed during spring phytoplanktonic blooms and were more pronounced in 2003. Generally, highest $\mid \delta \mathrm{pCO}_{2}$, temp $\mid$ values were observed in August. From January to May, the $\mathrm{pCO}_{2}$ dynamics was controlled by biological processes, as the increase of the $\delta \mathrm{pCO}_{2}$, temp is not sufficient to counteract the drop of the $\delta \mathrm{pCO}_{2}$, obs. From late spring to summer, the increase of $\mathrm{SpCO}_{2}$, obs was due to the combination of heterotrophic activities and the increase of temperature, as both $\delta \mathrm{pCO}_{2}$, bio and $\delta \mathrm{pCO}_{2}$, temp increased. In early fall, the opposite trends were observed with a drop of temperature and a consecutive decrease of heterotrophic activities. However, during this period some values of $\delta \mathrm{pCO}_{2}$, obs and $\delta \mathrm{pCO}_{2}$, bio increased (as shown by arrows in September-October 2001 and 2004 in Figure 6), and could be explained by low salinity events with higher DIC content, and/or resuspension of sediments with subsequent degradation of fresh organic matter (see critics on this method below). In fall and winter, the decrease of temperature is the dominant factor controlling the $\mathrm{pCO}_{2}$ dynamics. 
Table 1. Amplitude in the $\delta \mathrm{pCO}_{2}$, obs, $\delta \mathrm{pCO}_{2}$, bio, and $\delta \mathrm{pCO}_{2}$, temp Signals at Station Zeebrugge From 2001 to 2004 and Estimate of the T/B Ratio Computed According to Takahashi et al. [2002]

\begin{tabular}{ccccc}
\hline & $\delta \mathrm{pCO}_{2, \text { obs }}$ & $\delta \mathrm{pCO}_{2, \text { bio }}$ & $\delta \mathrm{pCO}_{2, \text { temp }}$ & $\mathrm{T} / \mathrm{B}$ \\
\hline 2001 & 641 & 635 & 343 & 0.54 \\
2002 & 562 & 670 & 382 & 0.57 \\
2003 & 804 & 823 & 486 & 0.59 \\
2004 & 884 & 650 & 373 & 0.57 \\
\hline
\end{tabular}

[20] Table 1 shows the annual amplitudes in the $\delta \mathrm{pCO}_{2}$, obs, $\delta \mathrm{pCO}_{2}$, bio, $\delta \mathrm{pCO}_{2}$, temp, and $\mathrm{T} / \mathrm{B}$ ratio for Zeebrugge station. The amplitude in $\delta \mathrm{pCO}_{2}$, bio was greater than $\delta \mathrm{pCO}_{2}$, temp, and the $\mathrm{T} / \mathrm{B}$ ratio was rather similar for the 4 years $(\sim 0.6)$ indicating that on an annual scale biological processes dominated over temperature effects. These results are in agreement with the output from the 1-D MIRO$\mathrm{CO}_{2}$ biogeochemical model for the Belgian coastal waters [Gypens et al., 2004] that yields a T/B ratio of 0.66 .

[21] As mentioned by Thomas et al. [2005b], the method developed by Takahashi et al. [2002] was designed for open oceanic systems and, in the case of coastal ecosystems, besides temperature and biology other physical/chemical processes can significantly affect the $\mathrm{pCO}_{2}$ dynamics: freshwater discharge, exchange between different water masses, sediment/water column exchanges, variations of TA and air-sea $\mathrm{CO}_{2}$ fluxes. In the present computations, these factors were inherently associated to the biological signal which can lead to misinterpretations of the results. Nevertheless, applying this method to the whole survey area for 2002 (highest temporal coverage among the 4 years), the different $\delta \mathrm{pCO}_{2}$ (not shown) displayed the same relative variations than the ones for Zeebrugge station and therefore a similar T/B $(\sim 0.6)$ is estimated. As explained above, Zeebrugge station is shallow and close to the mouth of the Scheldt estuary and $\mathrm{pCO}_{2}$ dynamics at this station is expected to be much more influenced by factors such as freshwater flow and sediment/water column exchanges than the whole plume area. Therefore these results indicate that the method of Takahashi et al. [2002] may be a reasonable approach to assess the qualitative relative importance of temperature and biological processes on the $\mathrm{pCO}_{2}$ dynamics in this system.

[22] Recently, Thomas et al. [2005b] used the same computations for the whole North Sea. They found that biological processes dominate over tempera- ture on the surface seawater $\mathrm{pCO}_{2}$ dynamics in the northern part of the North Sea $(\mathrm{T} / \mathrm{B}<1)$, whereas it was the contrary $(\mathrm{T} / \mathrm{B}>1)$ in the SBNS. They concluded that for the SBNS biological net effects were vanished through near balanced production and respiration processes in the well-mixed water column, as the absence of a summer thermocline avoided export of spring synthesized organic matter. However, the data set (CANOBA cruises) of Thomas et al. [2005b] was based on 4 cruises in August and November 2001 and February and May 2002. During the last cruise, the SBNS was sampled at the end of May, when the bloom of Phaeocystis $s p$. was probably already declining, as also suggested by the modeling study of K. Elkalay et al. (Biogeochemical 1D ERSEM ecosystem model applied to recent carbon dioxide and nutrient data in the North Sea, submitted to Journal of Marine Systems, 2006). These results suggested then that the $\mathrm{pCO}_{2}$, bio and therefore the T/B ratio were respectively underestimated and overestimated in their study. More recently, on the basis of a monthly survey carried on from June 2003 to May 2004, L.-S. Schiettecatte et al. (High temporal coverage of carbon dioxide measurements in the Southern Bight of the North Sea, submitted to Marine Chemistry, 2006) showed that the SBNS is a $\mathrm{CO}_{2}$ sink where biological processes were dominant over temperature on the surface $\mathrm{pCO}_{2}$ dynamics $(\mathrm{T} / \mathrm{B} \sim 0.8)$, with a possible export of the newly synthesized organic matter to the adjacent system and/or smaller export to the sediments.

\subsection{Net Ecosystem Production (NEP)}

[23] A system is defined as autotrophic when GPP exceeds CR (NEP $>0)$ and heterotrophic when CR exceeds GPP $(\mathrm{NEP}<0)$. NEP is relevant for $\mathrm{pCO}_{2}$ dynamics since in an autotrophic system, there is a net removal of $\mathrm{CO}_{2}$ from the water column, and conversely in a heterotrophic system there is a net release of $\mathrm{CO}_{2}$ to the water column. The net $\mathrm{CO}_{2}$ flux between the water column and the atmosphere will be further modulated by numerous other factors such as: other biogeochemical processes $\left(\mathrm{CaCO}_{3}\right.$ precipitation/dissolution), exchange of water with adjacent aquatic systems, residence time of the water mass within the system and decoupling of organic carbon production and degradation across the water column related to the physical settings of the system [e.g., Borges, 2005].

[24] Figure 7a shows computed monthly NEP values in 2003 estimated for the Scheldt plume using the LOICZ modeling procedure applied to 


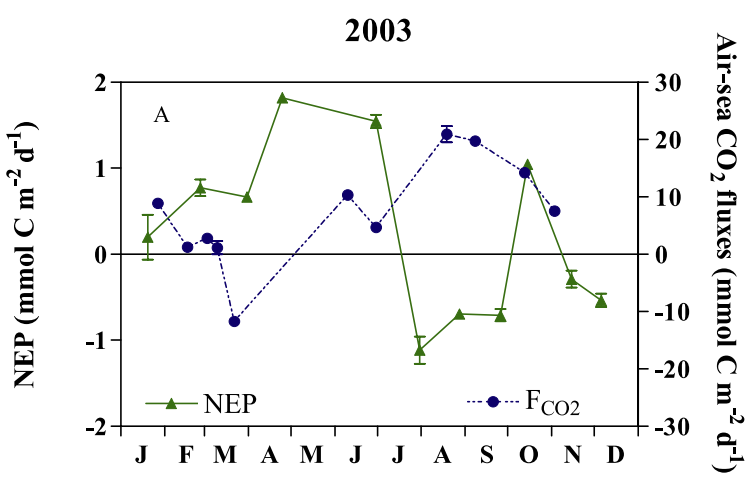

2003

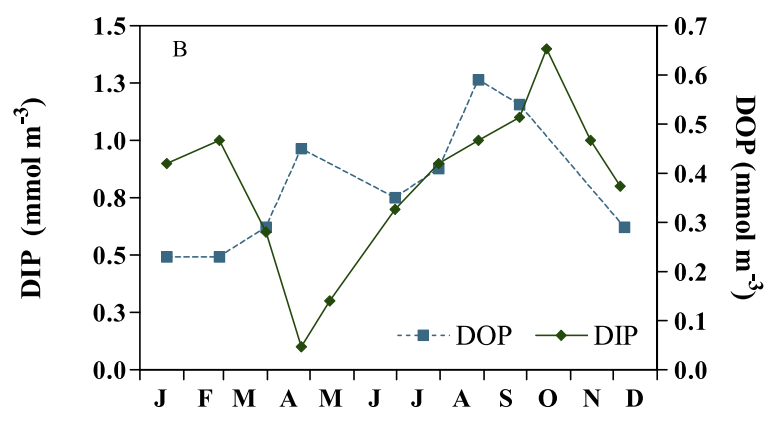

Figure 7. (a) Left axis: monthly net ecosystem production (NEP; mmol $\mathrm{C} \mathrm{m}^{-2} \mathrm{~d}^{-1}$; green triangles) in 2003 estimated from the Land Ocean Interaction in the Coastal Zone (LOICZ) budgeting procedure applied to dissolved inorganic phosphorus (DIP). Errors bars refer to standard errors computed from a Monte Carlo procedure (see text for details). Right axis: Averaged airsea $\mathrm{CO}_{2}$ fluxes $\left(\mathrm{F}_{\mathrm{CO} 2}\right.$ in mmol $\mathrm{C} \mathrm{m}^{-2} \mathrm{~d}^{-1}$; blue circles) computed from $\mathrm{pCO}_{2}$ data acquired in the whole plume (survey area approach), the gas transfer velocity parameterization as a function of wind speed given by Nightingale et al. [2000], and wind speed data from station Vlakte van de Raan. (b) Dissolved organic phosphate (DOP) and DIP in mmol $\mathrm{m}^{-3}$ in the Scheldt plume.

DIP (10 months sampling coverage in 2003), and air-sea $\mathrm{CO}_{2}$ fluxes from the survey area of the Scheldt plume (next section). From January to June and in October, the Scheldt plume was autotrophic (range $0.2 \pm 3.0$ to $1.8 \pm 0.0 \mathrm{mmol} \mathrm{C} \mathrm{m}{ }^{-2} \mathrm{~d}^{-1}$ ) and heterotrophic the rest of the year (range $-0.3 \pm 0.1$ to $-1.1 \pm 1.2 \mathrm{mmol} \mathrm{C} \mathrm{m} \mathrm{d}^{-1}$; Table 2). The strongest autotrophy was computed for April (1.8 \pm $0.0 \mathrm{mmol} \mathrm{C} \mathrm{m}^{-2} \mathrm{~d}^{-1}$ ), in relation to the spring diatoms-Phaeocystis bloom when surface seawater were strongly undersaturated in $\mathrm{CO}_{2}$ with respect to the atmosphere (Figure 5). Annually averaged NEP in the Scheldt plume was estimated to $0.2 \pm$ $3.7 \mathrm{mmol} \mathrm{C} \mathrm{m} \mathrm{d}^{-1}$, giving a metabolic status not significantly different from balance.
[25] Clearly, computed NEP values in spring during the phytoplanktonic bloom are too low to explain the decrease of $\mathrm{pCO}_{2}$ during that period (Figure 5, survey area approach). If we assume a mean TA of the Scheldt plume of $2450 \mu \mathrm{mol} \mathrm{kg}{ }^{-1}$, a decrease of about $300 \mu \mathrm{atm}$ of the surface $\mathrm{pCO}_{2}$ from early to mid March, and taking into account a mean air-sea $\mathrm{CO}_{2}$ fluxes of about $-5 \mathrm{mmolC} \mathrm{m}^{-2}$ $\mathrm{d}^{-1}$, it would give an approximated NEP based on DIC of about $6 \mathrm{mmolC} \mathrm{m}^{-2} \mathrm{~d}^{-1}$. This rough estimate is higher than the one based on DIP budget of $1 \mathrm{mmolC} \mathrm{m} \mathrm{m}^{-2} \mathrm{~d}^{-1}$ for the same period. Several problems arise from the use of DIP in this procedure. The first one deals with the ability of Phaeocystis sp to grow, under DIP depleted conditions, on dissolved organic phosphorus (DOP) by means of the alkaline phosphatase (AP). As Phaeocystis $s p$. is the third phytoplanktonic species to occur within this area after diatoms, the water column is depleted in DIP. In order to ensure their phosphate requirements, the Phaeocystis colonies de-repress (for DIP concentration below $0.5 \mathrm{mmol} \mathrm{m}^{-3}$ ) the enzyme AP [Veldhuis and Admiraal, 1987; Van Boekel and Veldhuis, 1990]. The APs are located on the phytoplanktonic cell surface and mineralize DOP to DIP through the hydrolysis of the P-O-C bond. Chlorophyll- $a$ (not shown) was highest during spring and consistent with the DIP decrease from February to end May due to photosynthetic activity whereas DOP increased during the same period (Figure $7 \mathrm{~b}$ ). The first peak of DOP (in April) is associated to a release from phytoplanktonic cells during primary production whereas the second one (August) should be associated to bacterial activities [van der Zee and Chou, 2005]. It is then possible that because of the physiological adaptation of Phaeocystis sp to grow on DOP, our NEP computed for spring could be underestimated. However, it is also obvious that DOP concentrations were still important throughout summer suggesting a continued remineralization by bacteria. Therefore the NEP during summer, estimated from DIP alone, could have led to a significant underestimation of the heterotrophy. As no DOP data were available for the inner Scheldt estuary and the SBNS boxes, it was not possible to integrate DOP in the present LOICZ budget.

[26] The second problem encountered from the present budget comes from the use of the Redfield ratio in order to convert the NEP into carbon from DIP. We assumed a molar $\mathrm{C} / \mathrm{P}$ ratio of 106:1. However, Phaeocystis $s p$ presents two life cycles. The first one is in the form of single flagellate cells evolving toward a colonial stage. These colonies 
Table 2. Monthly Averaged Plume Surface Area, Scheldt Discharge, Salinity, and Dissolved Inorganic Phosphorus in the Estuary, Plume, and SBNS Boxes, and $\triangle \mathrm{DIP}$ and computed NEP ${ }^{\mathrm{a}}$

\begin{tabular}{|c|c|c|c|c|c|c|c|c|c|c|}
\hline \multirow[b]{2}{*}{ Month } & \multirow[b]{2}{*}{ S } & \multirow[b]{2}{*}{ Q } & \multicolumn{3}{|c|}{ Sal } & \multicolumn{3}{|c|}{ DIP } & \multirow[b]{2}{*}{$\Delta \mathrm{DIP}$} & \multirow[b]{2}{*}{ NEP } \\
\hline & & & Estuary & Plume & SBNS & Estuary & Plume & SBNS & & \\
\hline January & 2974 & $37.6(22.9)$ & $22.5(2.5)$ & 32.5 (1.4) & $34.5(0.3)$ & $3.1(0.6)$ & $0.9(0.3)$ & $0.6(0.1)$ & 1.9 [2.5] & $0.2[0.3]$ \\
\hline February & 3329 & $23.1(13.6)$ & $20.6(3.3)$ & $30.6(2.6)$ & $34.5(0.4)$ & $3.2(0.5)$ & $1.0(0.3)$ & $0.5(0.1)$ & $7.3[0.9]$ & $0.8[0.1]$ \\
\hline March & 3535 & $15.4(5.8)$ & $21.3(2.7)$ & $31.4(1.2)$ & $34.3(0.2)$ & $2.8(0.3)$ & $0.6(0.4)$ & $0.1(0.0)$ & $6.3[0.5]$ & $0.7[0.1]$ \\
\hline April & 4499 & $10.3(3.1)$ & $24.1(2.2)$ & $31.0(0.7)$ & $34.5(0.0)$ & $2.1(0.6)$ & $0.1(0.1)$ & $0.1(0.0)$ & $17.2[0.1]$ & $1.8[0.0]$ \\
\hline June & 1569 & & $27.0(2.4)$ & $32.6(0.7)$ & $34.1(0.0)$ & $2.1(0.5)$ & $0.3(0.2)$ & $0.1(0.0)$ & $14.6[0.7]$ & $1.5[0.1]$ \\
\hline July & 1716 & $7.5(3.2)$ & $29.3(2.1)$ & $32.8(0.7)$ & $34.2(0.1)$ & $2.1(0.8)$ & $0.7(0.4)$ & $0.1(0.1)$ & $-10.5[1.5]$ & $-1.1[0.2]$ \\
\hline August & 3583 & $4.8(3.7)$ & $29.3(1.1)$ & $33.5(0.4)$ & $34.6(0.2)$ & $3.4(0.5)$ & $0.9(0.5)$ & $0.1(0.1)$ & $-6.6[0.5]$ & $-0.7[0.1]$ \\
\hline September & 3389 & $4.4(0.9)$ & $28.9(1.9)$ & $33.3(0.6)$ & $34.3(0.1)$ & $3.5(0.9)$ & $1.0(0.5)$ & $0.4(0.2)$ & $-6.7[0.7]$ & $-0.7[0.1]$ \\
\hline October & 2188 & $5.9(2.3)$ & $28.7(2.0)$ & $32.6(0.1)$ & $34.3(0.1)$ & $3.3(0.8)$ & $1.1(0.1)$ & $0.4(0.1)$ & $9.9[0.4]$ & $1.0[0.0]$ \\
\hline November & 1408 & $6.1(1.4)$ & $29.5(1.5)$ & $32.5(0.5)$ & $34.6(0.3)$ & $2.8(0.8)$ & $1.4(0.2)$ & $0.5(0.2)$ & $-2.7[0.9]$ & $-0.3[0.1]$ \\
\hline December & 2819 & $10.1(4.8)$ & $29.0(1.2)$ & $33.3(0.5)$ & $34.6(0.2)$ & $3.0(0.6)$ & $1.0(0.2)$ & $0.4(0.1)$ & $-5.1[0.7]$ & $-0.5[0.1]$ \\
\hline Mean & 2819 (985) & $12.0(12.3)$ & $25.8(3.8)$ & $32.4(1.5)$ & $34.4(0.3)$ & $2.5(0.9)$ & $0.8(0.4)$ & $0.3(0.2)$ & $2.3[34.5]$ & $0.2[3.7]$ \\
\hline
\end{tabular}

\footnotetext{
${ }^{\text {a }}$ Plume surface area, $\mathrm{S}$, in $\mathrm{km}^{2}$; Scheldt discharge, $\mathrm{Q}$, in $10^{6} \mathrm{~m}^{3} \mathrm{~d}^{-1}$; dissolved inorganic phosphorus, DIP, in mmol $\mathrm{m}^{-3}$; nonconservative fluxes

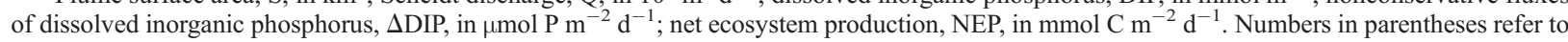
the standard deviations of the different averaged parameters, and numbers in brackets refer to the computed standard errors based on a Monte Carlo procedure (see text for details).
}

are characterized, under low nutrients concentration (probably nitrates), by the formation of an extracellular matrix rich in polysaccharides, leading to a $\mathrm{C} / \mathrm{P}$ molar ratio higher than $106: 1$ [Lancelot and Mathot, 1987; Schoemann et al., 2005]. In culture experiments, Jahnke [1989] showed that the $\mathrm{C} / \mathrm{P}$ molar ratio of Phaeocystis $s p$ under DIP deficiency conditions ranged between 128:1 and 568:1. Using these two extreme values, the NEP computed for April 2003 would range between 2.2 and $9.7 \mathrm{mmol} \mathrm{C} \mathrm{m} \mathrm{d}^{-1}$.

[27] Finally, Gazeau et al. [2005] pointed out the fact that, due to abiotic processes such as DIP adsorption and desorption to and from suspended particles and/or sediment, the use of a $\mathrm{C} / \mathrm{P}$ stoechiometrically linked budget to estimate NEP in the Scheldt inner estuary was strongly biased. These authors suggested net adsorption processes in the oligohaline part, while desorption processes could have introduced a bias in their results in the marine part of the estuary (due to an increase of pH; see Froelich [1988] for details). As suspended matter concentrations are of the same order of magnitude in the plume as the mouth of the estuary (L.-S. Schiettecatte, unpublished results), DIP desorption from suspended particles in the plume could be significant compared to DIP changes due to organic matter production and degradation. Indeed, Gazeau et al. [2005] estimated potential DIP desorption rates in the marine part of the inner Scheldt estuary ranging between 0.2 and $0.8 \mathrm{mmol}$ $\mathrm{P} \mathrm{m} \mathrm{m}^{-2} \mathrm{~d}^{-1}$, which if applicable to our study site would have lead to a strong underestimation of NEP.

\subsection{Air-Sea $\mathrm{CO}_{2}$ Fluxes in the Scheldt Plume}

[28] Figure 8 shows the air-sea $\mathrm{CO}_{2}$ fluxes computed for the Scheldt plume, from 2001 to 2004, from the survey area (blue circles) and Zeebrugge station (red squares) approaches using wind speed data from station Vlakte van de Raan and the $k$ wind parameterization of Nightingale et al. [2000]. The air-sea $\mathrm{CO}_{2}$ fluxes computed at the Zeebrugge station were, most of the time, one order of magnitude higher than those computed from the survey area approach. This is related to the higher $\mathrm{pCO}_{2}$ values at the Zeebrugge station as discussed above. For instance, both approaches showed that in 2002 the Scheldt plume was on average a net source of $\mathrm{CO}_{2}$ to the atmosphere of $19( \pm 4)$ and 2 ( \pm 3.1$)$ mmol $\mathrm{C} \mathrm{m}^{-2} \mathrm{~d}^{-1}$ for, respectively, Zeebrugge station and survey area approaches. A sink of atmospheric $\mathrm{CO}_{2}$ was only observed during the spring phytoplanktonic bloom for the area survey and Zeebrugge station approaches (up to

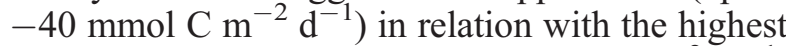
NEP observed in April $\left(1.8 \mathrm{mmol} \mathrm{C} \mathrm{m}^{-2} \mathrm{~d}^{-1}\right.$, Figure 7). During the rest of the year, surface waters were a source of $\mathrm{CO}_{2}$ to the atmosphere, even during the late summer bloom when a positive NEP value was estimated (October). Strong wind speed short terms events (up to $20 \mathrm{~m} \mathrm{~s}^{-1}$, Figure 2) were also responsible for high air-sea 
$\mathrm{CO}_{2}$ fluxes, up to $22 \mathrm{mmol} \mathrm{C} \mathrm{m}^{-2} \mathrm{~d}^{-1}$ for the survey area approach (referred to as $\mathrm{U}_{10}$ in Figure 8). Other events could be responsible for extreme air-sea $\mathrm{CO}_{2}$ flux values at the Zeebrugge station, such as the presence of lower salinity with higher $\mathrm{pCO}_{2}$ and/or remineralization of resuspended organic matter (referred to as S and DIC in Figure 8). These processes could be directly associated to storm events, although the presence of lower salinity waters was also dependent on the overall wind speed direction.

[29] Figure 7a shows that there was a general agreement in the trends of ecosystem metabolism and air-sea $\mathrm{CO}_{2}$ fluxes. The sink of atmospheric $\mathrm{CO}_{2}$ was observed during the autotrophic spring period while the highest emission of $\mathrm{CO}_{2}$ to the atmosphere occurred during the strongly heterotrophic summer period. However, discrepancies were observed on a monthly basis: from early February to mid March, the Scheldt plume was a source of $\mathrm{CO}_{2}$ to the atmosphere although characterized by a positive NEP. A similar situation was also observed in late May and October. Besides the potential problems associated with the use of a $\mathrm{C} / \mathrm{P}$ stoechiometrically linked budget discussed above, processes other than organic carbon production and consumption can contribute to air-sea $\mathrm{CO}_{2}$ fluxes, such as inputs of $\mathrm{CO}_{2}$ from the inner Scheldt estuary, as discussed hereafter.

[30] Table 3 shows annually integrated air-sea $\mathrm{CO}_{2}$ fluxes based on the survey area approach. On the basis of results from 2002, which was the year with the best temporal coverage, the plume of the Scheldt acted as a net source of $\mathrm{CO}_{2}$ to the atmosphere of $0.7( \pm 1.1) \mathrm{mol} \mathrm{C} \mathrm{m} \mathrm{yr}^{-1}$ (N\&al). By contrast, in 2001, the plume of the Scheldt would be a sink for atmospheric $\mathrm{CO}_{2}$ $\left(-1.7 \pm 1.8 \mathrm{~mol} \mathrm{C} \mathrm{m} \mathrm{mr}^{-1} ; \mathrm{N} \& \mathrm{al}\right)$. In 2003 and 2004, $\mathrm{CO}_{2}$ fluxes were higher than in 2002 , respectively $(2.6 \pm 1.1$ and $1.9 \pm 1.7 \mathrm{~mol} \mathrm{C}$ $\mathrm{m}^{-2} \mathrm{yr}^{-1}$ ). As shown in Figure 8, there was a lack of data in 2001 during summer, when surface waters showed the highest $\mathrm{CO}_{2}$ oversaturation and consequently high $\mathrm{CO}_{2}$ emissions to the atmosphere. In 2003 and 2004, the lack of data during the spring phytoplanktonic bloom led to the overestimation of the annually integrated air-sea $\mathrm{CO}_{2}$ flux. This clearly highlights the need of a strong temporal coverage in DIC dynamics studies for coastal environments.

[31] Air-sea $\mathrm{CO}_{2}$ fluxes computed for 2002 from the survey area approach using wind speed data from the offshore station Europlatform (Figure 1) gave values similar to the ones based on wind speed data from station Vlakte van de Raan, located in the plume $\left(0.7 \pm 1.0 \mathrm{~mol} \mathrm{C} \mathrm{m}^{-2} \mathrm{yr}^{-1}\right.$ for N\&al, not shown in Table 3). The use of wind speed data from the two coastal meteorological stations (Cadzand and Vlissingen) gave lower airsea $\mathrm{CO}_{2}$ fluxes in 2002 , respectively $0.2( \pm 0.8)$ and $0.4( \pm 0.6) \mathrm{mol} \mathrm{C} \mathrm{m}{ }^{-2} \mathrm{yr}^{-1}$ using the N\&al parameterization (not shown in Table 3). Wind speed measurements at Cadzand and Vlissingen are affected by orographic effects; hence the computed air-sea $\mathrm{CO}_{2}$ fluxes are lower than those computed from data obtained at the other meteorological stations.

[32] The $k$-wind parameterization from L\&M was determined from $\mathrm{SF}_{6}$ mass balance budgets in lakes. According to Wanninkhof [1992], tracers experiments in lakes give $k$ values that are underestimates for open ocean conditions at the same given wind speed due to fetch limitation. This could explain the lower $\mathrm{CO}_{2}$ flux values computed using $k$-wind $\mathrm{L} \& \mathrm{M}$ relation, $0.5( \pm 0.9) \mathrm{mol} \mathrm{C} \mathrm{m}^{-2}$ $\mathrm{yr}^{-1}$ for 2002 than those computed using the other parameterizations (Table 3). Fluxes computed from $k$-wind parameterization of $\mathrm{W}$ and $\mathrm{W} \& \mathrm{McG}$ gave higher values than those computed from the N\&al parameterization, respectively $1( \pm 1.4)$ and 1.3 $( \pm 1.3)$ mol C m${ }^{-2} \mathrm{yr}^{-1}$, using wind speed data from station Vlakte van de Raan for 2002 (Table 3). The W, W\&McG and N\&alk-wind parameterizations were established for open ocean conditions but using different approaches. The $\mathrm{W} k$-wind relationship is based on an ocean average gas transfer velocity derived from the global ocean inventory of bomb ${ }^{14} \mathrm{C}$ of DIC given by Broecker et al. [1985]. The W\&McGk-wind relationship is based on $\mathrm{CO}_{2}$ covariance measurements in the North Atlantic and the fit to data was established to constrain the global ocean inventory of bomb ${ }^{14} \mathrm{C}$ of DIC given by Broecker et al. [1985]. It has been claimed that the bomb radiocarbon ocean inventory of Broecker et al. [1985] is an overestimate; hence the W and W\&McG parameterizations would overestimate $k$ [Hesshaimer et al., 1994; Peacock, 2004]. The $\mathrm{N} \& a \mathrm{l} k$-wind parameterization is based on two experiments with dual tracers $\left(\mathrm{SF}_{6}\right.$ and $\left.{ }^{3} \mathrm{He}\right)$ carried out in the SBNS.

[33] The annually integrated air-sea $\mathrm{CO}_{2}$ fluxes we computed in this study for year 2002 are about $50 \%$ lower than of those computed by Borges and Frankignoulle [2002] (Table 3). These authors estimated annual air-sea $\mathrm{CO}_{2}$ areal fluxes from a composite annual cycle based on campaigns car- 
2001

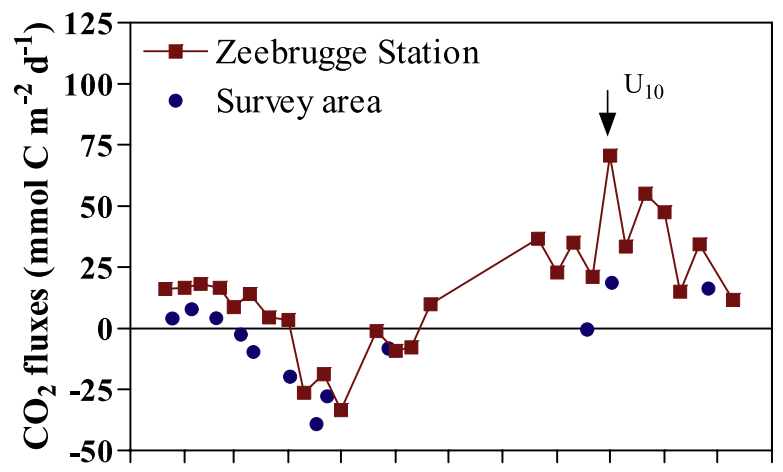

2003

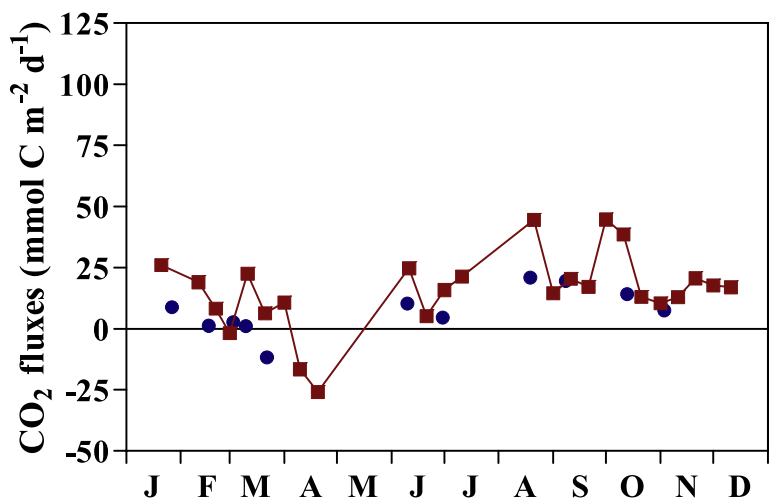

2002

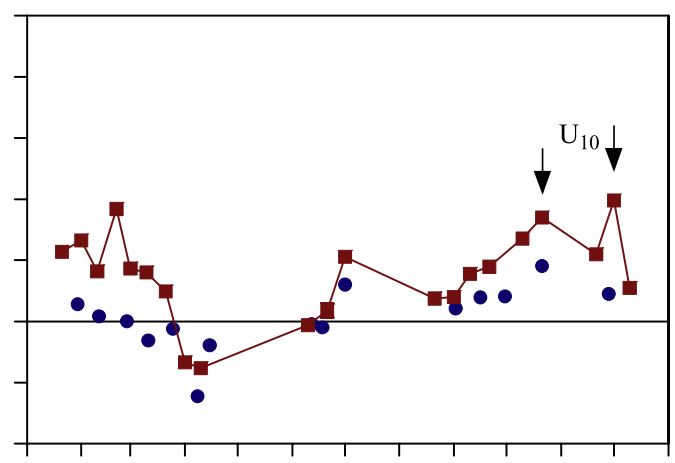

2004

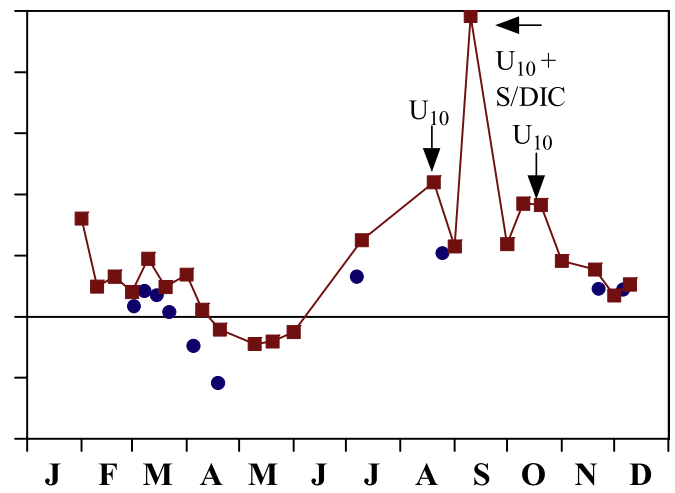

Figure 8. Air-sea $\mathrm{CO}_{2}\left(\mathrm{mmol} \mathrm{C} \mathrm{m} \mathrm{m}^{-2} \mathrm{~d}^{-1)}\right.$ fluxes from spatially integrated data (survey area approach; blue circles) and at Zeebrugge station (red squares) from 2001 to 2004. For air-sea $\mathrm{CO}_{2}$ fluxes computation, the gas transfer velocity parameterization as a function of wind speed given by Nightingale et al. [2000] and wind speed data from station Vlakte van de Raan were used. $\mathrm{U}_{10}$ refers to strong wind speed events, $\mathrm{S}$ refers to an observed decrease of salinity, and DIC refers to inputs of dissolved inorganic carbon from the sediments.

ried out over 4 years (1996 to 1999). This approach probably biased the air-sea $\mathrm{CO}_{2}$ fluxes toward higher values, since the annual average $\Delta \mathrm{pCO}_{2}$ value of Borges and Frankignoulle [2002] is more than two times higher than the one we obtained for 2002, 16 and $7 \mu \mathrm{atm}$, respectively.

[34] The net annual emission from the Scheldt plume (Table 3) ranges between $1.0( \pm 3.7)$ and

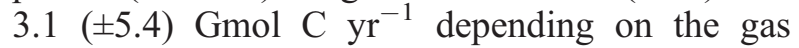
transfer velocity parameterization. This represents between 7 and $22 \%$ of the emission of $\mathrm{CO}_{2}$ from the inner Scheldt estuary of $141 \mathrm{Gmol} \mathrm{C} \mathrm{yr}^{-1}$ given by Frankignoulle et al. [1998] and between 9 and $27 \%$ of the emission of $\mathrm{CO}_{2}$ from the inner Scheldt estuary of $112 \mathrm{Gmol} \mathrm{C} \mathrm{yr}^{-1}$ given by Gazeau et al. [2005]. These $\mathrm{CO}_{2}$ emission estimates are below those given by Borges and Frankignoulle [2002] of 2.3 to $4.4 \mathrm{Gmol} \mathrm{C} \mathrm{yr}^{-1}$ because the latter values are derived from higher air-sea $\mathrm{CO}_{2}$ flux estimates as discussed above, and to the use of a constant surface area for the plume of $2100 \mathrm{~km}^{2}$ (here we used plume surface area values on cruise by cruise basis).

\subsection{DIC Budget in the Scheldt Plume: Preliminary Results}

[35] Annually integrated, TADIC from the inner estuary represents $1.6 \mathrm{Gmol} \mathrm{C} \mathrm{yr}^{-1}(123 \%$ of the air-sea $\mathrm{CO}_{2}$ fluxes in 2002; $1.3 \mathrm{Gmol} \mathrm{C} \mathrm{yr}^{-1}$, Table 3). Biological processes have been shown to be important drivers of $\mathrm{pCO}_{2}$ seasonal variations within the Scheldt plume, but estimates of NEP based on a DIP budget suffer from several problems (see above). However, the estimated NEP (0.3 Gmol $\left.\mathrm{C} \mathrm{yr}^{-1}\right)$ allows to balance the DIC input/output budget. It could then suggest that an additional organic carbon input is not necessary to explain the $\mathrm{CO}_{2}$ emission from the Scheldt plume as originally assumed by Borges and Frankignoulle [2002]. This assumption was based on an inorganic and organic carbon budget that suffered from a bias in the areal air-sea $\mathrm{CO}_{2}$ flux 
Table 3. Annually Integrated Air-Sea $\mathrm{CO}_{2}$ Fluxes in the Scheldt Plume Computed Using Surface Water $\mathrm{pCO} 2$ Data Acquired During the Survey Area, the Gas Transfer Velocity Parameterizations as a Function of Wind Speed, as Well as Wind Speed Data From Station Vlakte van de Raan ${ }^{\mathrm{a}}$

\begin{tabular}{|c|c|c|c|c|c|}
\hline & Year & L\&M & $\mathrm{W}$ & W\&McG & N\&al \\
\hline \multicolumn{6}{|c|}{ Fluxes, mol $\mathrm{C} \mathrm{m}^{-2} y r^{-1}$} \\
\hline \multirow[t]{4}{*}{ This study } & 2001 & $-1.3(1.4)$ & $-2.1(2.3)$ & $-1.7(2.0)$ & $-1.7(1.8)$ \\
\hline & 2002 & $0.5(0.9)$ & $1.0(1.4)$ & $1.3(1.3)$ & 0.7 (1.1) \\
\hline & 2003 & $2.0(0.7)$ & $3.3(1.2)$ & $2.9(0.9)$ & $2.6(1.1)$ \\
\hline & 2004 & $1.4(1.3)$ & $2.4(2.1)$ & $2.0(1.9)$ & $1.9(1.7)$ \\
\hline Borges and Frankignoulle [2002] & $1996-1999$ & 1.1 & 2.0 & 2.8 & 1.5 \\
\hline \multicolumn{6}{|c|}{ Emissions, Gmol C $y r^{-1}$} \\
\hline This study & 2002 & $1.0(3.7)$ & $1.9(6.2)$ & $3.1(5.4)$ & $1.3(5.0)$ \\
\hline Borges and Frankignoulle [2002] $]^{\mathrm{b}}$ & $1996-1999$ & 2.3 & 4.2 & 4.4 & 3.1 \\
\hline \multicolumn{6}{|l|}{$\%$ of the Scheldt estuary emission } \\
\hline Frankignoulle et al. [1998] & & 7 & 13 & 22 & 9 \\
\hline Gazeau et al. [2005] & & 9 & 17 & 27 & 12 \\
\hline
\end{tabular}

${ }^{\mathrm{a}}$ Air-sea $\mathrm{CO}_{2}$ fluxes in mol $\mathrm{C} \mathrm{m}^{-2} \mathrm{yr}^{-1}$. Gas transfer velocity parameterizations as a function of wind speed given by Liss and Merlivat [1986] (L\&M), Wanninkhof [1992] (W), Wanninkhof and McGillis [1999] (W\&McG), and Nightingale et al. [2000] (N\&al). Numbers in parentheses indicate standard errors of the computed fluxes. Annually integrated $\mathrm{CO}_{2}$ emissions from the Scheldt plume were estimated from these computed fluxes and estimated surface areas of the plume during each survey. These $\mathrm{CO}_{2}$ emissions are compared to the ones calculated by Frankignoulle et al. [1998] and Gazeau et al. [2005] in the inner Scheldt estuary.

${ }^{\mathrm{b}} \mathrm{CO}_{2}$ emission estimated from the annually integrated fluxes and a mean surface area of $2100 \mathrm{~km}^{2}$.

estimates and from the use of a constant surface area of the plume, as discussed above. This is also consistent with the model of Soetaert and Herman [1995] that simulates an almost full consumption of river POC (90\%) with the Scheldt inner estuary (i.e., only $10 \%$ is exported to the adjacent coastal zone). In the same way, carbon inputs of the Rhine/ Meuse estuary and French estuaries (Seine and Somme) would have a negligible effect on the carbon dynamics off the Belgian coast. Another assumption that could emerge from this is that DIC mass balance budgets can be highly sensitive to the choice of the $k$-wind parameterization. The use of annually integrated air-sea $\mathrm{CO}_{2}$ fluxes computed from other $k$-wind parameterizations also leads to inconsistencies in the present DIC mass balance budget, as also shown, for instance, in the Scheldt inner estuary [Gazeau et al., 2005].

\section{Conclusions}

[36] In the case of a heterogeneous and dynamic coastal ecosystem, such as an estuarine plume, a data set from a fixed station allows to describe qualitatively the dynamics of $\mathrm{pCO}_{2}$ and its main biogeochemical drivers. However, the reliable computation of air-sea $\mathrm{CO}_{2}$ fluxes requires a survey area approach with a high temporal and spatial resolution. Indeed, short-term events at daily to weekly scales related to strong winds and/or biological processes can generate high air-sea $\mathrm{CO}_{2}$ fluxes and bias the direction and intensity of the net annual air-sea $\mathrm{CO}_{2}$ flux in the case of low temporal sampling coverage.

[37] In the Scheldt estuarine plume, biological processes compared to temperature effects dominate the seasonal variations of $\mathrm{pCO}_{2}$. A LOICZ mass balance budget of DIP showed an alternation of autotrophic and heterotrophic periods in accordance to previously described succession of phytoplankton species and biomass, and heterotrophic organisms. The patterns in the seasonal $\mathrm{pCO}_{2}$ and air-sea $\mathrm{CO}_{2}$ flux variations are consistent with the alternation of autotrophic and heterotrophic periods. However, the use of a LOICZ mass balance budget based on DIP is problematic because of physiological characteristics of Phaeocystis $s p$. that dominates the spring bloom biomass and production in the study area. Importantly, the polysaccharide-matrix characteristic of the Phaeocystis $s p$. colonies leads to significant variations in the carbon to phosphorous molar ration. Also, Phaeocystis $s p$. can grow on dissolved organic phosphate during dissolved inorganic phosphate depletion. Gazeau et al. [2005] also attributed discrepancies in the inner Scheldt estuary between the NEP computed from the LOICZ modeling procedure based on DIP and the one from in situ oxygen incubations to DIP desorption from particles.

[38] The plume of the Scheldt is on an annual scale a net source of $\mathrm{CO}_{2}$ to the atmosphere $(0.7 \mathrm{~mol} \mathrm{C}$ 
$\mathrm{m}^{-2} \mathrm{yr}^{-1}$ ). On the basis of a preliminary DIC budget, we hypothesized that the inputs of $\mathrm{CO}_{2}$ from the Scheldt inner estuary are largely responsible for the net annual $\mathrm{CO}_{2}$ emission to the atmosphere from the plume.

\section{Acknowledgments}

[39] We thank the captains and crew of the R/V Belgica as well as Joan Backers (Management Unit of the North Sea Mathematical Models) for their help in running the underway $\mathrm{pCO}_{2}$ system, Management Unit of the North Sea Mathematical Models for thermosalinograph data, S.V. Smith for its invaluable help for the implementation of the LOICZ budget, and two anonymous referees for pertinent and constructive comments on a previous version of the manuscript. This research was supported by the European Union in the framework of the EUROTROPH project (contract EVK3-CT-2000-00040) and the CARBOOCEAN project (contract 511176-2), by the Belgian Federal Office for Scientific, Technical and Cultural Affairs (contract EV/12/20C) and by the Fonds National de la Recherche Scientifique (contract 2.4545.02), where A.V.B. is a research associate. This is MARE publication 83 and NIOO publication 3817. This work is dedicated to Michel Frankignoulle, former director of the Chemical Oceanography Unit, who left us on 13 March 2005.

\section{References}

Borges, A. V. (2005), Do we have enough pieces of the jigsaw to integrate $\mathrm{CO} 2$ fluxes in the Coastal Ocean?, Estuaries, 28(1), 3-27.

Borges, A. V., and M. Frankignoulle (1999), Daily and seasonal variations of the partial pressure of $\mathrm{CO}_{2}$ in surface seawater along Belgian and southern Dutch coastal areas, J. Mar. Syst., 19, 251-266.

Borges, A. V., and M. Frankignoulle (2002), Distribution and air-water exchange of carbon dioxide in the Scheldt plume off the Belgian coast, Biogeochemistry, 59, 41-67.

Borges, A. V., B. Delille, and M. Frankignoulle (2005), Budgeting sinks and sources of $\mathrm{CO}_{2}$ in the coastal ocean: Diversity of ecosystems counts, Geophys. Res. Lett., 32, L14601, doi:10.1029/2005GL023053.

Broecker, W., T.-H. Peng, G. Ostlund, and M. Stuiver (1985), The distribution of bomb radiocarbon in the ocean, J. Geophys. Res., 90, 6953-6970.

Cai, W., Z. A. Wang, and Y. Wang (2003), The role of marshdominated heterotrophic continental margins in transport of $\mathrm{CO}_{2}$ between the atmosphere, the land-sea interface and the ocean, Geophys. Res. Lett., 30(16), 1849, doi:10.1029/ 2003GL017633.

Copin-Montégut, C. (1988), A new formula for the effect of temperature on the partial pressure of carbon dioxide in seawater, Mar. Chem., 25, 29-37, (Corrigendum, Mar. Chem., 27, 143-144, 1989.).

Dagg, M., R. Benner, S. Lohrenz, and D. Lawrence (2004), Transformation of dissolved and particulate materials on continental shelves influenced by large rivers: Plume processes, Cont. Shelf Res., 24, 833-858.

de Haas, H., T. C. E. van Weering, and H. de Stigter (2002), Organic carbon in shelf seas: Sinks or sources, processes and products, Cont. Shelf Res., 22(5), 691-717.
Dickson, A., and C. Goyet (Eds.) (1994), Handbook of Methods for the Analysis of the Various Parameters of the Carbon Dioxide System in Sea Water, Carbon Dioxide Inf. Anal. Cent., Oak Ridge, Tenn.

Fettweiss, M., and D. Van den Eynde (2003), The mud deposits and the high turbidity in the Belgian-Dutch coastal zone, southern bight of the North Sea, Cont. Shelf Res., 23, 669691.

Frankignoulle, M., and A. V. Borges (2001), European continental shelf as a significant sink for atmospheric $\mathrm{CO}_{2}$, Global Biogeochem. Cycles, 15(3), 569-576.

Frankignoulle, M., G. Abril, A. Borges, I. Bourge, C. Canon, B. Delille, E. Libert, and J.-M. Théate (1998), Carbon dioxide emission from European estuaries, Science, 282, 434436.

Frankignoulle, M., A. V. Borges, and R. Biondo (2001), A new design of equilibrator to monitor carbon dioxide in highly dynamic and turbid environments, Water Res., 35, 13441347.

Froelich, P. N. (1988), Kinetic control of dissolved phosphate in natural rivers and estuaries: A primer on the phosphate buffer mechanism, Limnol. Oceanogr., 33(4), part 2, 649668.

Gattuso, J.-P., M. Frankignoulle, and R. Wollast (1998), Carbon and carbonate metabolism in coastal aquatic ecosystems Annu. Rev. Ecol. Syst., 29, 405-433.

Gazeau, F., J.-P. Gattuso, J. J. Middelburg, N. Brion, L.-S. Schiettecatte, M. Frankignoulle, and A. V. Borges (2005), Planktonic and whole system metabolism in a nutrient rich estuary (the Schledt estuary), Estuaries, 28(6), 868-883.

Gordon, D. C. J., P. R. Boudreau, K. H. Mann, J.-E. Ong, W. L. Silvert, S. V. Smith, G. Wattayakorn, F. Wulff, and T. Yanagi (1996), LOICZ biogeochemical modeling guidelines, LOICZ Rep. Stud., 5, pp. 1-96, R. Neth. Inst. for Sea Res., Texel, Netherlands.

Grasshoff, K., M. Ehrhardt and K. Kremling (Eds.) (1983), Methods of Seawater Analysis, Verlag Chemie, Basel, Germany.

Gypens, N., C. Lancelot, and A. V. Borges (2004), Carbon dynamics and $\mathrm{CO}_{2}$ air-sea exchanges in the eutrophicated coastal waters of the Southern Bight of the North Sea: A modelling study, Biogeosciences, 1, 561-589.

Hesshaimer, V., M. Heimann, and I. Levin (1994), Radiocarbon evidence for a smaller oceanic carbon dioxide sink than previously believed, Nature, 370, 201-203.

Jahnke, J. (1989), The light and temperature dependence of growth rate and elemental composition of Phaeocystis globosa Scherffel and P. pouchetii (Har.) Lagerh. in batch cultures, Neth. J. Sea Res., 23, 15-21.

Kaul, L., and P. Froelich (1984), Modelling estuarine nutrient biogeochemistry in a simple system, Geochim. Cosmochim. Acta, 48, 1417-1433.

Ketchum, B. H. (1983), Estuarine characteristics, in Estuaries and Enclosed Seas, edited by B. H. Ketchum, pp. 1-13, Elsevier, New York.

Lacroix, G., K. Ruddick, J. Ozer, and C. Lancelot (2004), Modelling the impact of the Scheldt and Rhine/Meuse plumes on the salinity distribution in Belgian waters (southern North Sea), J. Sea Res., 52, 149-163.

Lancelot, C., and S. Mathot (1987), Dynamics of a Phaeocystis-dominated spring bloom in Belgian coastal waters. 1. Phytoplankton activities and related parameters, Mar. Ecol. Prog. Ser., 37, 239-248.

Lancelot, C., Y. Spitz, N. Gypens, K. Ruddick, S. Becquevort, V. Rousseau, G. Lacroix, and G. Billen (2005), Modelling diatom and Phaeocystis blooms and nutrient cycles in the 
Southern Bight of the North Sea: The MIRO model, Mar. Ecol. Prog. Ser., 289, 63-78.

Liss, P. S., and L. Merlivat (1986), Air-sea exchange rates: Introduction and synthesis, in The Role of Air-Sea Exchanges in Geochemical Cycling, edited by P. Buat-Ménard, pp. 113-118, Springer, New York.

Nightingale, P. D., G. Malin, C. S. Law, A. J. Watson, P. S. Liss, M. I. Liddicoat, J. Boutin, and R. C. Upstill-Goddard (2000), In situ evaluation of air-sea gas exchange parameterizations using novel conservative and volatile tracers, Global Biogeochem. Cycles, 14, 373-387.

Nihoul, J. C. J., and F. Ronday (1975), The influence of tidal stress on the residual circulation, Tellus, 29, 484-490.

Nihoul, J. C. J., and J. H. Hecq (1984), Influence of residual circulation on the physico-chemical characteristics of water masses and the dynamic of ecosystems in the Belgian coastal zone, Cont. Shelf Res., 3, 167-174.

Odum, H. T. (1956), Primary production in flowing waters, Limnol. Oceanogr., 1(2), 102-117.

OSPARCOM (2002), Quality status report 2000, OSPAR Comm., London. (Available at http://www.ospar.com)

Peacock, S. (2004), Debate over the ocean bomb radiocarbon sink: Closing the gap, Global Biogeochem. Cycles, 18, GB2022, doi:10.1029/2003GB002211.

Reid, P. C., C. Lancelot, W. W. C. Gieskes, E. Hagmeier, and G. Weichart (1990), Phytoplankton of the North Sea and its dynamics: A review, Neth. J. Sea Res., 26(2-4), 295331.

Rousseau, V., A. Leynaert, N. Daoud, and C. Lancelot (2002), Diatom succession, silicification and silicic acid availability in Belgian coastal waters (southern North Sea), Mar. Ecol. Prog. Ser., 236, 61-73.

Schettini, C. A. F., K. N. Kuroshima, J. P. Fo, L. R. Rorig, and C. Resgalla Jr. (1998), Oceanographic and ecological aspects of the Itjaai-acu river plume during high discharge period, Anais Acad. Brasileria de Cienc., 70, 335-351.

Schoemann, V., S. Becquevort, J. Stefels, V. Rousseau, and C. Lancelot (2005), Phaeocystis blooms in the global ocean and their controlling mechanisms: A review, J. Sea Res., 53, $43-66$.

Smith, S. V., and J. T. Hollibaugh (1993), Coastal metabolism and the oceanic carbon balance, Rev. Geophys., 31, 75-89.

Soetaert, K., and P. M. J. Herman (1995), Carbon flows in the Westerschelde estuary (The Netherlands) evaluated by means of an ecosystem model (MOSES), Hydrobiologia, $311,247-266$.
Soetaert, K., J. J. Middelburg, C. Heip, P. Meire, S. Van Damme, and T. Maris (2006), Long-term change in dissolved inorganic nutrients in the heterotrophic Scheldt estuary (Belgium, the Netherlands), Limnol. Oceanogr., 51(1), part 2, 409-423.

Takahashi, T., et al. (2002), Global sea-air $\mathrm{CO}_{2}$ flux based on climatological surface ocean $\mathrm{pCO}_{2}$, and seasonal biological and temperature effects, Deep Sea Res., Part II, 49, 1601-1622.

Thomas, H., Y. Bozec, K. Elkalay, and H. J. W. de Baar (2004), Enhanced open ocean storage of $\mathrm{CO}_{2}$ from shelf sea pumping, Science, 304, 1005-1008.

Thomas, H., Y. Bozec, H. J. W. de Baar, K. Elkalay, M. Frankignoulle, L.-S. Schiettecatte, G. Kattner, and A. V. Borges (2005a), The carbon budget of the North Sea, Biogeosciences, 2, 87-96.

Thomas, H., Y. Bozec, K. Elkalay, H. J. W. de Baar, A. V. Borges, and L. S. Schiettecatte (2005b), Controls of the surface water partial pressure of $\mathrm{CO} 2$ in the North Sea, Biogeosciences, 2, 323-334.

Tsunogai, S., S. Watanabe, and T. Sato (1999), Is there a "continental shelf pump" for the absorption of atmospheric $\mathrm{CO}_{2}$ ?, Tellus, Ser. B, 5, 701-712.

Van Boekel, W. H. M., and M. J. W. Veldhuis (1990), Regulation of alkaline-phosphatase synthesis in Phaeocystis sp. Mar. Ecol. Prog. Ser., 61, 281-289.

van der Zee, C., and L. Chou (2005), Seasonal cycling of phosphorus in the Southern Bight of the North Sea, Biogeosciences, 2(1), 27-42.

Veldhuis, M. J. W., and W. Admiraal (1987), Influence of phosphate-depletion on the growth and colony formation of Phaeocystis pouchetii, Mar. Biol., 95, 47-54.

Wanninkhof, R. H. (1992), Relationship between wind speed and gas exchange over the ocean, J. Geophys. Res., 97(C5), $7373-7382$.

Wanninkhof, R., and W. R. McGillis (1999), A cubic relationship between air-sea $\mathrm{CO} 2$ exchange and wind speed, Geophys. Res. Lett., 26, 1889-1892.

Wollast, R. (1988), The Scheldt Estuary, in Pollution of the North Sea, An Assessment, edited by W. Salomon, pp. 185193, Springer, New York.

Wollast, R. (1998), The global coastal ocean, in The Sea, vol. 10, edited by K. H. Brink and A. R. Robinson, pp. 213-252, John Wiley, Hoboken, N. J.

Yang, L. (1998), Modelling of hydrodynamic processes in the Belgian coastal zone, Ph.D. thesis, 208 pp., Katholieke Univ. Leuven, Leuven, Belgium. 